\title{
Os protestos no Brasil em tempos de crise $(2011-2016)^{1}$
}

\author{
Luciana Tatagiba² (D) \\ Andreia Galvão ${ }^{3}$
}

\begin{abstract}
Este artigo se propõe a analisar as características dos protestos no Brasil entre 2011 e 2016, um contexto socioeconômico e político marcado pelas contradições e pelo ocaso dos governos petistas. A análise está baseada em um banco de dados de protesto constituído a partir do jornal Folha de S. Paulo. Sustentamos que os protestos antecedem a eclosão da crise econômica e que, quando atingem o pico, em 2013, produzem mudanças no contexto político, abrindo oportunidades políticas inéditas para que um conjunto heterogêneo de atores, à direita e à esquerda do PT, manifestasse suas divergências em relação ao governo. Os protestos evidenciam os limites da política de conciliação de classes dos governos petistas e conformam um cenário de instabilidade que contribui para o impeachment de Rousseff, de modo que não há uma descontinuidade entre 2013 e 2015-2016. O padrão de protesto verificado nesse período caracteriza-se pela combinação de duas dinâmicas distintas: polarização política e heterogeneização de atores e reivindicações.

Palavras-chave: protestos; crise; governos petistas
\end{abstract}

\section{Introdução}

O vigor e a persistência das mobilizações verificadas no Brasil a partir da segunda década dos anos 2000 têm estimulado um salutar desenvolvimento do campo de estudos sobre os protestos, uma área de investigação ainda embrionária na academia brasileira. Os principais focos dos novos estudos são os eventos de 2013 e 2015-2016, no geral analisados a partir de sua relação com a crise política que culminou no impeachment de Dilma Rousseff. Apesar de serem pesquisas ainda em desenvolvimento, já são significativas suas contribuições para a compreensão sobre quem protesta, por que

\footnotetext{
1 Versões preliminares deste artigo foram apresentadas em vários congressos da área. Agradecemos as críticas e sugestões feitas pelos debatedores e audiência. Agradecemos também a leitura atenta dos pareceristas da Opinião Pública. O banco de dados, com as variáveis selecionadas para esse texto, está disponível para download na página deste artigo no site do Cesop: <https://www.cesop.unicamp.br/por/opiniao_publica>.

2 Universidade Estadual de Campinas. Campinas (SP), Brasil. E-mail: <tatagiba@g.unicamp.br>.

3 Universidade Estadual de Campinas. Campinas (SP), Brasil. E-mail: <agalvao@unicamp.br>.
} 
protesta, contra quem protesta e como protesta, havendo inclusive esforços para comparar os protestos no Brasil com ciclos globais de mobilização 4 .

Essa literatura pode ser dividida em dois grandes campos, que correspondem grosso modo à filiação teórica de seus autores. De um lado, os trabalhos vinculados ao campo de estudos dos movimentos sociais priorizam o como da mobilização (a partir de conceitos como identidade, enquadramento simbólico, infraestrutura organizacional, repertórios), destacando as formas como movimentos sociais reagem às oportunidades e ameaças do contexto político no qual estão inseridos e buscam alterar esse contexto. De outro, os trabalhos inspirados na tradição marxista dão ênfase ao impacto da dinâmica do capitalismo sobre os padrões do protesto, destacando as classes sociais mobilizadas (um aspecto negligenciado em grande parte das análises de movimentos sociais) e estabelecendo conexões entre os planos nacional e global.

Apesar de esses campos, assim como as perspectivas teóricas neles predominantes, terem se desenvolvido paralelamente, verifica-se uma recente aproximação entre eles, estimulada por uma promissora agenda de pesquisa internacional que busca "trazer o capitalismo de volta" aos estudos dos movimentos sociais (Hetland e Goodwin, 2013; Barker et al., 2013; Della Porta, 2015). Esse diálogo permite problematizar as formas pelas quais os ciclos de crescimento e a crise do capitalismo, em associação com as dinâmicas sociopolíticas nacionais, configuram os cenários do confronto político em distintos e distantes espaços geográficos.

Em sintonia com essa perspectiva, tem sido desenvolvida uma proposta de abordagem integrada dos protestos (Galvão e Tatagiba, 2018), que busca articular a teoria do confronto político à teoria marxista, associando economia e política, classe e outros pertencimentos, trabalho e movimentos sociais, o nacional e o global. A abordagem integrada permite identificar a relação entre os diferentes movimentos sociais, sejam eles ligados ao trabalho, como o movimento sindical, ou a outras identidades e objetivos, de modo a explorar tanto as especificidades quanto as similaridades e conexões entre diferentes movimentos e ondas de mobilização. Esse ponto de partida incita-nos a olhar para além das especificidades de um movimento, evento de protesto ou campanha. Isso requer, de um lado, compreender as oportunidades e ameaças políticas às quais os atores respondem, ou seja, as dimensões do processo político; de outro, recuperar as bases estruturais do conflito. Para além das contingências relacionadas às mudanças de regime (dimensão geralmente abarcada nos estudos de movimentos sociais por meio do conceito de oportunidade política), os movimentos sociais contemporâneos respondem, de forma não unívoca, à dinâmica do capitalismo e suas crises ${ }^{5}$.

\footnotetext{
4 Cf., entre outros, Braga (2013), Cava e Cocco (2014), Estanque (2014), Gohn (2014), Cavalcante (2015), Alonso e Mische (2015) e Bringel e Players (2015).

5 A relação entre protestos e crise econômica tem suscitado um crescente debate na literatura, principalmente após a crise de 2008 e a onda de protestos que Ihe seguiu. Uma vertente interessante busca relacionar o contexto macroeconômico com os sentimentos subjetivos de privação. Para uma aproximação ao debate, ver Grasso e Giugni (2016).
} 
O contexto de crise do capitalismo neoliberal inaugurado em 2008 teve um profundo impacto nas condições de vida dos subalternos. A adoção de medidas de austeridade provocou o aumento do custo de vida, intensificou a precarização do trabalho, deteriorou os salários, degradou a qualidade dos serviços urbanos e agravou problemas decorrentes da falta de acesso a terra, água e moradia, gerando variados conflitos. Esse processo se verifica, com particularidades e temporalidades distintas, em diferentes países. A chegada da crise ao Brasil é temporalmente defasada se comparada aos países centrais. Isso se deve às especificidades do modelo de desenvolvimento implementado nos governos petistas, um modelo que não rompeu com o capitalismo neoliberal (Boito, 2012), ao mesmo tempo em que promoveu um reformismo fraco, sem confronto com o capital (Singer, 2012). A paradoxal combinação entre uma política macroeconômica neoliberal e a ampliação do papel do Estado como indutor do desenvolvimento possibilitou a adoção de medidas de distribuição de renda e proteção social, bem como a maior permeabilidade do Estado a movimentos sociais e sindicais (Abers, Serafim e Tatagiba, 2014). Esse modelo, consolidado no segundo governo Lula, foi viabilizado pela constituição de uma frente política neodesenvolvimentista, conformada por frações da burguesia e das classes populares (Boito, 2012), que respaldou o governo e sua política de conciliação de classes, o lulismo (Singer, 2012). A tendência à acomodação de interesses conflitantes, porém, não foi capaz de reduzir, de modo consistente e generalizado, a expressão de conflitos. Como procuramos mostrar neste artigo, os protestos precedem a eclosão da crise econômica, que se torna manifesta em 2015. As classes populares, organizadas em diversos movimentos sociais, manifestaram em várias ocasiões seu descontentamento com alguns aspectos da política governamental. Setores da burguesia e das classes médias, por sua vez, passaram a expressar sua insatisfação diante das políticas sociais e da intervenção do Estado na economia, de modo que, já em meados do primeiro mandato de Rousseff, a conciliação de classes deu lugar a uma "frente única burguesa antidesenvolvimentista" (Singer, 2015, p. 67).

Este artigo se propõe a analisar as características dos protestos nesse contexto socioeconômico e político particular, marcado pelas contradições e pelo ocaso dos governos petistas. A análise está baseada em um inédito banco de dados de protesto no Brasil, desenvolvido pelas autoras no âmbito do projeto "O confronto político da ascensão à crise dos governos petistas (2003-2016)" (Tatagiba e Galvão, 2018). Neste artigo abordamos o período compreendido entre 2011, primeiro ano de governo de Dilma Rousseff, e 2016, ano do golpe jurídico-parlamentar que levou à sua destituição e substituição por seu vice, Michel Temer. Selecionamos duas dimensões para a análise: os atores mobilizados e as reivindicações, buscando compreender suas variações ao longo do período.

No que se refere à relação entre protestos e crise, nosso argumento é de que os protestos expressam insatisfações tanto daqueles setores que buscavam avançar nas reformas quanto daqueles que buscavam restaurar o status quo. Quando atingem o pico, 
em 2013, produzem mudanças no contexto político, abrindo oportunidades políticas inéditas para que um conjunto heterogêneo de atores, inclusive as forças oposicionistas, manifestasse suas divergências em relação ao governo, conformando um cenário de instabilidade e crise política que contribui para o impeachment de Rousseff. O padrão de protesto caracteriza-se pela combinação de duas dinâmicas distintas: polarização política (em torno do eixo PT X anti-PT) ${ }^{6}$ e heterogeneização de atores e reivindicações, com uma permanência importante de conflitos de classe e o fortalecimento de conflitos estruturados em torno de outros pertencimentos identitários. Como buscamos evidenciar ao longo do artigo, apesar da centralidade da crise política ativada pelo antipetismo, a cena do confronto político não se reduz aos termos da polarização política, mas a extravasa de forma significativa. Essa combinação de polarização e heterogeneização expressa os limites da capacidade do lulismo de incorporar demandas e controlar conflitos, limites que se agudizam com a crise econômica.

O texto está dividido em quatro seções: na primeira, apresentamos algumas notas metodológicas, que detalham a composição de nosso banco de dados; na segunda, discutimos a relação entre crise e protesto; na terceira, apresentamos o perfil de quem protesta e na quarta tratamos das reivindicações mais frequentes no período em questão.

\section{Notas metodológicas: potencialidades e limites da base de dados $^{7}$}

Nossa pesquisa baseia-se na metodologia de análise de eventos de protesto (AEP), uma metodologia criada no campo de estudos de movimentos sociais, que consiste na produção de um catálogo de eventos de protestos a partir da definição de um conjunto de variáveis vinculadas às perguntas da pesquisa. As bases de dados mais comuns são os jornais, embora mais recentemente outras fontes estejam sendo utilizadas, como os registros policiais e as informações dos meios de comunicação em rede (Olsak, 1989; Koopmans e Rucht, 2002; Hutter, 2014).

A principal vantagem do método é o fato de permitir lidar com um conjunto variado de temas e movimentos sociais e construir séries históricas que possibilitam identificar

\footnotetext{
6 A referência à polarização política como dimensão que marca essa conjuntura de crise tem suscitado controvérsias (Ortellado, Solano e Ribeiro, 2016; Miguel, 2018). Nosso entendimento é de que a polarização política entre PT $x$ anti-PT tornou-se o eixo estruturador do confronto político entre os atores relevantes no pós-2013, organizando os embates discursivos na arena pública, com implicações diretas sobre os padrões de mobilização social e eleitoral. A forma como os contendores atuaram foi, contudo, muito distinta. No eixo antipetista, a polarização esteve acompanhada por um processo de radicalização política. Esse processo de radicalização - que não será tratado neste artigo - expressa o modus operandi da nova direita brasileira, uma direita radical que traz a violência, prática e discursiva, como dimensão central do seu repertório de ação.

7 Agradecemos a consultoria da colega de departamento, professora Andréa Freitas, na modelagem do banco de dados e treinamento de nossa equipe, e aos bolsistas de iniciação científica Ana Clara Rocha, Leonardo Joanes da Silva, Larissa Melo, Gleisson Belotti e Larissa Vicentim pelo trabalho no preenchimento do banco. Agradecemos a Leonardo Joanes o apoio na preparação dos dados utilizados neste artigo, bem como na consolidação da base de dados.
} 
variações nos padrões de protesto ao longo do tempo e do espaço, algo que os métodos tradicionais de estudos de movimentos sociais, como o estudo de caso e as abordagens mais qualitativas (Olsak, 1989; Hutter, 2014), não permitem fazer. A AEP é particularmente útil nos estudos comparados. Especificamente no âmbito deste artigo, a AEP oferece a possibilidade de compreender de forma articulada as mudanças no contexto político e nos padrões de protesto.

Apesar de ser um método muito utilizado, a AEP não é isenta de problemas. Uma de suas desvantagens é o problema da seletividade e da tendenciosidade das fontes. No caso dos jornais impressos, os estudos mostram que a cobertura varia em função do padrão editorial do jornal, do ator que convoca o protesto, do tamanho do protesto e sua capilaridade territorial, da natureza da reivindicação, do nível de dano envolvido e do local onde ocorre (Johnson, Sears e McConahay, 1971; Franzosi, 1987; Koopmans, Neidhardt e Rucht, 1999; Koopmans e Rucht, 2002). Quanto mais violento, maior e mais longo um evento, maior a probabilidade de ser reportado pela mídia (Klandermans e Staggenborn, 2002). Portanto, um catálogo de eventos nunca expressará a totalidade destes num interregno de tempo, mas apenas aqueles que foram capazes de furar os bloqueios e "virar notícia", o que, de certo modo, é um indicador de sucesso dos contendores, embora nem sempre o enquadramento da mídia Ihes seja favorável.

Neste artigo, utilizamos como fonte a Folha de S. Paulo (FSP), um dos jornais diários de maior circulação nacional, com sede no estado de São Paulo. A escolha da FSP está relacionada ao acesso ao seu acervo digital, no qual são disponibilizadas todas as edições impressas desde $1921^{8}$. A regularidade do acesso à notícia, a cobertura nacional e a funcionalidade da plataforma são fatores positivos em face dos objetivos aqui propostos. Mas a fonte também implica vieses para nossa análise. O primeiro deles diz respeito à linha editorial da FSP, que, principalmente a partir de 2006 (Biroli e Mantovani, 2014) com a cobertura dos escândalos do Mensalão e da Lava Jato, contribuiu para a construção da narrativa antipetista. A parcialidade e o partidarismo podem ter impactado as informações sobre os protestos, com subnotificação dos eventos em defesa do governo e/ou do PT e maior cobertura dos convocados pela oposição. O segundo viés refere-se ao peso do Sudeste $(59,6 \%)^{9}$, em particular o estado de São Paulo $(40 \%)$, em nosso universo. Portanto, ao falarmos em tendência nacional, é importante levar esses dados em consideração. Por fim, o terceiro problema diz respeito à qualidade da informação, principalmente no que se refere às organizações que convocaram os protestos e ao número de participantes, duas variáveis com alto número de missing em nosso banco ${ }^{10}$.

Em estudos futuros seria importante ampliar as fontes, incluindo a mídia alternativa e buscar jornais com inserção regional variada. Por ora, buscamos minimizar

\footnotetext{
8 Disponível em: <https://acervo.folha.com.br/index.do>. Acesso entre: 13 mar. 2016 e 15 jun. 2018.

9 A participação das demais regiões foi a seguinte: Nordeste $(13,7 \%)$, Centro-Oeste $(11,9 \%)$, Sul $(9,2 \%)$ e Norte $(5,5 \%)$.

10 Esse não é, contudo, um problema específico da FSP, como vemos em Olsak (1989).
} 
os problemas cotejando os resultados da pesquisa com outros bancos disponíveis (como o Dieese e o Dataluta). No caso das greves, por exemplo, captamos uma curva similar aos dados fornecidos pelo Dieese (ver Gráficos 1 e 3), embora esses últimos informem uma frequência muito superior à de nosso banco. O mesmo se pode dizer em relação às ocupações de terra, talvez o tipo de protestos mais subdimensionado de nossa base, na comparação com os dados fornecidos pelo banco Dataluta ${ }^{11}$. Contudo, mesmo nesse caso, quando projetamos a curva das ocupações de terra entre 2003 e 2016 ${ }^{12}$, vemos uma mesma tendência nos dois bancos: maior frequência no primeiro governo Lula, queda na segunda gestão, que se acentua no governo Rousseff, quando caem para menos da metade do verificado na série histórica. Outro apoio importante tem sido a realização de pesquisas qualitativas, principalmente sob a forma de entrevistas em profundidade com lideranças de movimentos sociais, novos coletivos e lideranças sindicais, o que tem nos permitido suprir eventuais lacunas na cobertura do nosso banco e ponderar nossas conclusões, considerando que nossos dados expressam tendências gerais.

Uma das particularidades do nosso banco é tratar a ação coletiva contenciosa de uma forma ampla. Nele são registradas ações convocadas por organizações de movimentos sociais e sindicatos de trabalhadores, bem como manifestações "espontâneas", convocadas por coletivos ou indivíduos não organizados, compreendendo ações diversas como greves, ocupações, passeatas, intervenção artística, depredação, escrachos contra políticos, bloqueio de estradas, rebeliões etc. Nossa unidade de análise é o evento de protesto. Definimos evento de protesto como ações coletivas (envolvendo pelo menos duas pessoas), iniciadas por grupos da sociedade, de natureza extrainstitucional (são eventos públicos que rompem com a rotina e instauram ou ameaçam instaurar algum tipo de dano) e voltadas a sustentar reivindicações ou queixas que, se atendidas, afetariam o interesse de outras pessoas (Tilly, 1978). Nesse sentido, não incluímos em nossa base um conjunto de outras práticas que compõem o repertório dos movimentos, como ações de formação junto as suas bases, reuniões com apoiadores, atuação institucional, lobby etc.

A operacionalização do conceito tem como principal desafio definir se o que a notícia reporta é um evento ou se são eventos múltiplos, o que significa estabelecer fronteiras temporais e espaciais (Olsak, 1989). Para que o evento seja definido como um evento, todas as seguintes características devem estar presentes: ter a mesma data de início, não haver interrupção, responder à mesma "convocação" e sustentar a mesma reivindicação/queixa, mesmo que com diferentes ações e/ou ocorrendo em diferentes localidades. Por exemplo, a manifestação pelo impeachment convocada pelo Movimento Brasil Livre (MBL) em 15/3/2015 ocorreu em dezenas de cidades, o que nos levou a considerá-la um evento único. A estrutura do nosso banco nos permite coletar a informação

11 Disponível em: <http://www2.fct.unesp.br/nera/projetos/dataluta_brasil_2016.pdf>. Acesso em: 7 maio 2018.

12 Neste artigo trabalhamos a base entre 2011 e 2016, mas já temos dados coletados para os governos Lula (2003-2010). 
para cada cidade mencionada na reportagem, mas todas elas receberam um mesmo código de evento. Isso nos permite trabalhar a informação agregada por evento ou desagregada por cidade. Para o período entre $1 / 1 / 2011$ e 31/08/2016, nosso banco possui 1.285 registros agregados por evento, 2.072 desagregados por cidade e 2.548 notícias de protestos (um mesmo evento de protesto pode ser objeto de várias reportagens, o que é comum em campanhas longas, como a ocupação de uma escola ou uma greve, por exemplo). Neste artigo utilizamos a informação agregada por evento, à exceção do Gráfico 2, onde comparamos por evento e por cidade.

Para localizar os eventos de protesto, a equipe da pesquisa acessou o acervo da Folha13 e leu os cadernos "Poder", "Mercado" e "Cotidiano", entre 1/1/2011 e 31/8/2016. As informações foram registradas no banco montado na plataforma Acess, estruturado em duas tabelas, a Tabela Geral, onde são registradas as informações agregadas por evento, e a Tabela Específica, onde são registradas as informações por cidade.

Nosso banco possui 24 variáveis e o artigo trabalha três delas: data de início do protesto, grupo social e reivindicação, sendo que as duas últimas são variáveis múltiplas com até quatro entradas. Grupos sociais são as categorias sociais que protestam. Para identificá-los, partimos da informação que nos dá a FSP - por exemplo, quando afirma "mulheres protestam", "trabalhadores protestam" etc. Na ausência dessa informação, derivamos os grupos sociais da(s) organização(ões) que convoca(m) e/ou da(s) reivindicação(ões). Na primeira codificação identificamos 23 grupos sociais, que depois se tornaram 15 grupos (ver Gráfico 7). As reivindicações/queixas apresentadas nos protestos também são registradas conforme informado pela FSP e posteriormente codificadas. Na primeira codificação identificamos 39 reivindicações, reagrupadas em dez para fins analíticos (ver Gráfico 9, p. 85).

\section{Os protestos e a crise}

Nossa base de dados registra 1.285 protestos entre $1 / 1 / 2011$, primeiro dia do governo Rousseff, e 31/8/2016, quando ela é definitivamente afastada pelo Senado, com uma média de 222,6 protestos por ano.

13 Disponível em: <https://acervo.folha.com.br/index.do>. Acesso entre: 13 mar. 2016 e 15 jun. 2018. 


\section{Gráfico 1 \\ Frequência anual dos protestos}

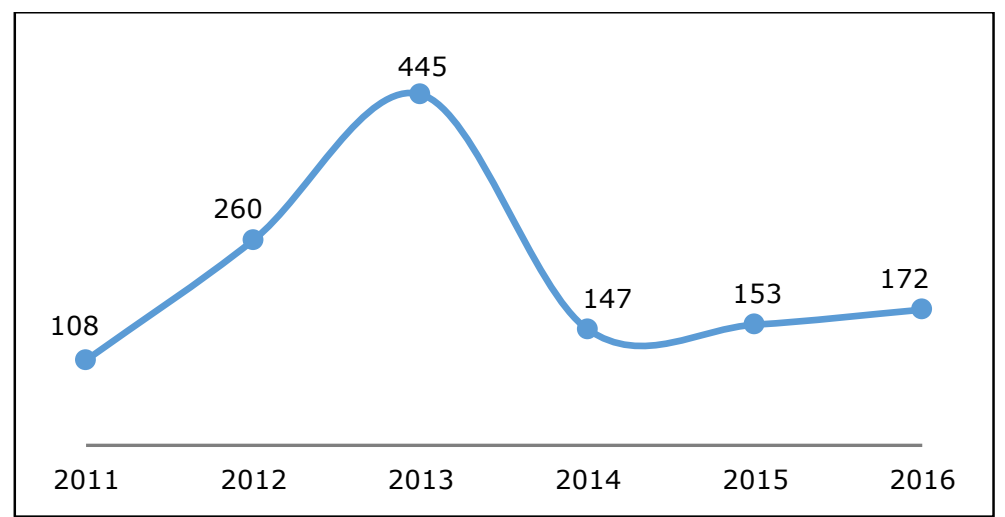

Fonte: Elaborado pelas autoras a partir de Tatagiba e Galvão (2018). *Frequência anual dos protestos entre 1/1/2011 e 31/8/2016, agregada por evento $(\mathrm{N}=1285)$.

Como se pode observar no Gráfico 1, os protestos seguiram uma trajetória oscilante. O ano de 2012 apresenta uma curva ascendente, registrando um aumento de $140 \%$ em relação a 2011 e um comportamento acima da média, o que sugere que o caldeirão de insatisfações que explode em 2013 já estava aquecendo desde o ano anterior. Em 2013 os protestos alcançam o dobro da média do período, constituindo o ponto mais alto da curva. Esse período de intensa mobilização, precipitado pela reivindicação da redução da tarifa dos transportes públicos, ficou conhecido como Jornadas de Junho ${ }^{14}$. Após um declínio em 2014, possivelmente em função do processo eleitoral, os protestos ganharam novo fôlego no âmbito da campanha pelo impeachment de Rousseff, a partir de 2015, mas o crescimento observado não retoma o patamar de 2013. A variação anual é mais tímida e inferior à média do período, com 153 protestos em 2015 e 172 em $2016^{15}$. Apesar disso, estamos considerando que 2015-2016 representa um novo pico de mobilização em virtude da difusão territorial dos protestos e do número de participantes neles envolvido ${ }^{16}$.

\footnotetext{
14 Já temos um considerável número de trabalhos sobre junho de 2013. Graças à iniciativa do pesquisador Jonas Medeiros, esse material foi organizado, de forma coletiva e colaborativa, e está disponível no endereço: <https://pt. wikiversity.org/wiki/Junho_de_2013_-_bibliografia?fbclid=IwAR16vt-e1n7M0NwnVJ4wX0lgP57h3gVy28v0HjQv9C7XzR2a4Q3Ov6UNIM>. Acesso em: 25 out. 2018. 15 Quando consideramos o total de protestos em 2016, ou seja, até 31/12/2016, contabilizamos 245 protestos, acima da média do período, mas ainda abaixo de 2012.

16 A difusão territorial dos protestos é registrada no nosso banco pela variável "âmbito do protesto", classificada em nacional (quando envolve dois ou mais estados), estadual (quando envolve dois ou mais municípios de um mesmo estado), municipal (quando envolve dois ou mais bairros em um mesmo município) ou local (quando é realizado em apenas um local, que pode ser uma ocupação, marcha em uma avenida, bloqueio de uma pista etc.). Mais de $50 \%$ dos protestos, em todos os anos do intervalo, são de âmbito local. Os protestos locais envolvem menor nível de coordenação entre os atores e recursos, quando comparados aos demais âmbitos.
} 
O Gráfico 2 compara o número de eventos convocados e o número de cidades nos quais ocorreram. Quanto maior o intervalo entre os valores, maior a difusão territorial dos protestos naquele ano. Nossos dados sugerem que, muito embora a conflitividade acionada em junho de 2013 tenha se espalhado por diversas cidades brasileiras, ela parece ser caracterizada por uma dinâmica mais descentralizada e heterogênea, com diferentes alvos, organizações e demandas. Já no caso de 2015-2016, as redes pró e contra o impeachment foram capazes de produzir a difusão territorial de um único evento por várias cidades, o que denota capacidade de organização e mobilização.

\section{Gráfico 2}

\section{Protestos agregados por evento e desagregados por cidade (2011-2016)}

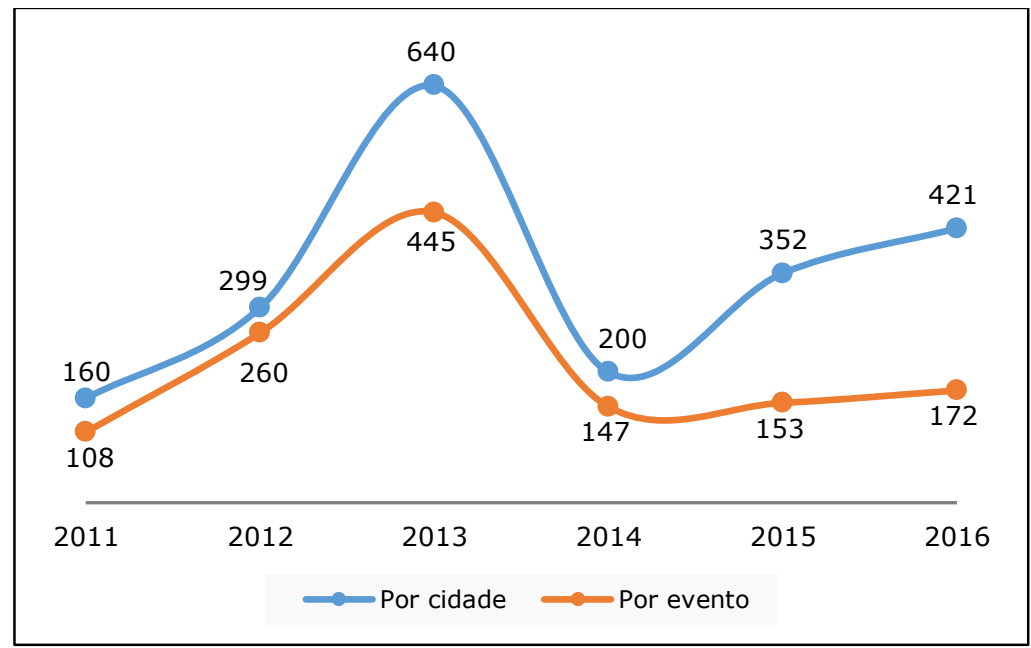

Fonte: Elaborado pelas autoras a partir de Tatagiba e Galvão (2018).

*Protestos agregados por evento $(\mathrm{N}=1.285)$ e desagregados por cidade $(\mathrm{N}=2.072)$.

Nesse sentido, diferentemente da perspectiva de Alonso e Mische (2015), não observamos uma descontinuidade entre 2013 e os protestos posteriores. Pelo contrário, compreendemos esses protestos como parte de um mesmo processo histórico de mudanças, que abrange dimensões políticas, econômicas e culturais. A relação entre a intensificação dos protestos, a partir de 2012, e a deterioração do ambiente político e econômico é complexa e dificilmente pode ser apreendida em termos de uma causalidade unívoca. Além disso, como apresentamos adiante, os dados não nos permitem apontar com precisão quando tem início esse processo de deterioração. De todo modo, parece plausível supor que a intensificação dos protestos está relacionada tanto ao impacto da 
crise do capitalismo em sociedades periféricas, como a brasileira, quanto ao legado contraditório dos governos do $\mathrm{PT}^{17}$.

De um lado, as políticas públicas implementadas pelos governos Lula e Rousseff promoveram melhorias no mercado de trabalho e na distribuição de renda, possibilitando a redução do desemprego, das desigualdades e das hierarquias sociais ${ }^{18}$. Esses resultados repercutiram no processo político e nas formas de ação coletiva, provocando reorientações significativas entre os subalternos: novos grupos foram reconhecidos como atores políticos e integrados à arena política. Destacam-se, nesse sentido, as políticas de combate à violência contra a mulher, de reconhecimento da comunidade LGBT, de inserção produtiva de mulheres agricultoras, dentre outras. Para usar os termos de Dagnino, seria possível afirmar que as políticas sociais e de reconhecimento de minorias afetaram os alicerces do "autoritarismo social" no Brasil ${ }^{19}$.

De outro lado, os limites de um governo de conciliação de classes geraram insatisfação por parte de movimentos sociais tradicionalmente próximos ao PT, que passaram a denunciar a insuficiência das políticas sociais e seus efeitos perversos. Essas críticas provocaram rupturas organizacionais (a exemplo daquelas verificadas nos movimentos sindical, dos sem-teto e dos sem-terra $)^{20}$, e disputas crescentes na esquerda. A ampliação da escolarização, sobretudo em nível superior, e do acesso à internet produziu mudanças simbólicas e culturais entre a juventude (Ridenti, 2013a, 2013b) ${ }^{21}$, estimulando novas demandas e formas de ação. Grupos autonomistas, que defendem a horizontalidade contra a hierarquia de partidos e sindicatos, emergem especialmente nesse segmento, como o Movimento Passe Livre (MPL), que deflagrou as Jornadas de 2013.

Assim, é possível dizer que os protestos evidenciam queixas e insatisfações de um conjunto muito diverso de atores sociais, indicando uma conflitividade social crescente que extrapola a capacidade de incorporação política do lulismo. Nos anos de 2011 e 2012, os primeiros de nossa série, ocorrem protestos pela redução da tarifa do transporte público em várias cidades, com forte repressão policial; greves do funcionalismo público,

\footnotetext{
17 Não temos condições de desenvolver a questão da crise do capitalismo no escopo deste artigo. A importância das formas específicas do capitalismo, especialmente aquilo que Purdy (2017) denomina de "o neoliberalismo das administrações petistas", também é destacada em sua análise dos protestos de junho de 2013. O autor ainda chama a atenção para as transformações nas formas e condições da luta de classes, o que converge com o que procuramos indicar aqui.

18 Os gastos sociais em âmbito federal passaram de 12,6\% do PIB em 2003 para 15\% em 2015. O salário mínimo foi valorizado em $76 \%$ nesse mesmo período e a participação dos salários no PIB aumentou 4,1 pontos percentuais entre 2004 e 2014 (Rossi, Dweck e Oliveira, 2018).

19 A desigualdade econômica e os níveis extremos de pobreza são apenas o aspecto mais visível da organização desigual e hierárquica que subjaz às relações sociais na América Latina (Dagnino, 2000). Para capturar as dimensões culturais dessa desigualdade, a autora cunha o termo autoritarismo social.

20 A reforma da previdência de 2003 provocou um processo de cisão na CUT e a criação de novas organizações, próximas ao PSTU e ao PSOL, como a Conlutas e a Intersindical (Galvão, 2012). Em 2011, dirigentes do MST, MTD, Consulta Popular e Via Campesina anunciaram sua saída dessas organizações, por considerarem que elas haviam capitulado ante o governo e ao seu "projeto político rebaixado".

21 Nesse sentido, é importante considerar o papel crescente da internet nas novas formas de ativismo social no Brasil, um tema que não temos, contudo, condição de desenvolver neste artigo.
} 
principalmente nas universidades federais; protestos dos setores religiosos contra direitos de minorias e a liberalização do aborto; protestos difusos contra a corrupção, convocados pela internet; protestos contra as obras do Programa de Aceleração do Crescimento (PAC), sobretudo a construção das hidrelétricas, e contra o Novo Código Florestal, que uniram ambientalistas, comunidades tradicionais e movimentos populares e territoriais; campanhas do MST como o Abril Vermelho, por reforma agrária; protestos contra a divisão dos royalties do petróleo e contra a privatização dos aeroportos, protagonizados por sindicatos e movimentos populares.

Esse conjunto diverso de forças sociais foi às ruas já em 2011 e 2012, para pressionar por mudanças ou para resistir a elas. Nesse sentido, tanto a hipótese do consentimento passivo das massas e do consentimento ativo das direções sindicais ${ }^{22}$ quanto a hipótese da intensificação do uso de repertórios de confronto (Silva, 2017, p. 11) precisam ser colocadas em perspectiva e relativizada ${ }^{23}$. O comportamento dos movimentos não é uniforme: enquanto alguns privilegiaram a participação institucional, reorientando sua atuação para os canais de interlocução abertos pelo governo, outros enfatizaram a ação direta ou, ainda, a combinação entre ambas as formas de ação, mesclando greves e ocupações com negociação, por exemplo. Ou seja, o maior ativismo institucional (Abers e Tatagiba, 2015; Galvão, 2012) observado nesse período não eliminou as ações contenciosas, mas o confronto oscilou ao longo dos anos e conforme os movimentos sociais considerados.

Tomemos o caso do movimento sindical. Embora seja possível encontrar protestos unindo trabalhadores e industriais contra a alta taxa de juros praticada pelo governo, a disputa entre capital e trabalho não esteve ausente nesse período. Essa disputa pode ser observada, entre outros, por meio dos indicadores de greves que, segundo o Dieese, crescem mais claramente a partir de 2008 (Boito, Galvão e Marcelino, 2015). Como evidenciado no Gráfico 3, os indicadores de greves apresentam um comportamento similar à curva de protestos encontrada em nossa base, com pico em 2013 e novo aumento em 2016, apesar da mudança de contexto entre um pico e outro:

\footnotetext{
22 As primeiras, "seduzidas pelas políticas públicas redistributivas e pelos modestos ganhos salariais advindos do crescimento econômico, aderiram momentaneamente ao governo", ao passo que as segundas foram "seduzidas por posições no aparato estatal, fora as incontáveis vantagens materiais proporcionadas pelo controle dos fundos de pensão" (Braga, 2012, p. 37).

23 Os próprios indicadores utilizados por Silva (2017) mostram a necessidade de nuançar sua hipótese: os dados de greve do Dieese mostram uma tendência de queda entre 2003 e 2007, seguidos por uma retomada a partir de 2008; os dados do Dataluta apontam para uma queda de ocupações de terra a partir de 2007, com uma recuperação a partir de 2011 , embora em um patamar mais baixo.
} 


\section{Total de greves registradas no Brasil (2011-2016)}

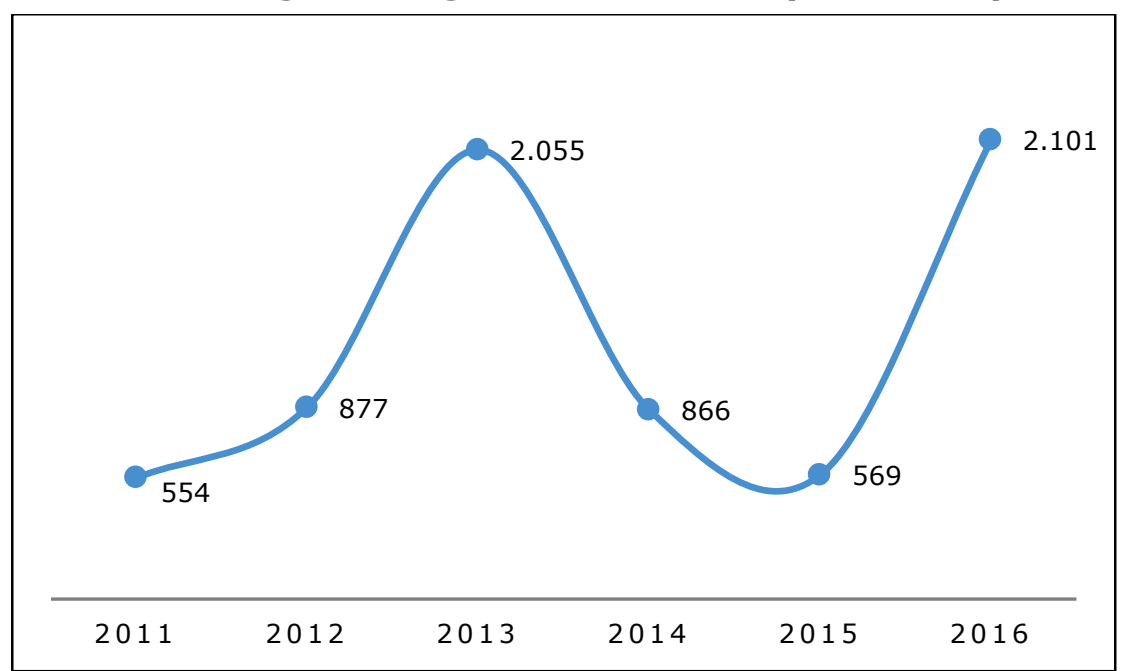

Fonte: Elaborado pelas autoras a partir de dados do Sistema de Acompanhamento de Greves-Dieese.

A questão da taxa de juros é especialmente interessante para compreender a mudança no padrão de protestos. A redução da taxa de juros e a adoção de uma "nova matriz econômica", baseada no maior ativismo estatal, no primeiro ano de governo de Dilma Rousseff geraram resultados inesperados. A resposta ao que Singer (2015) denomina "ensaio desenvolvimentista" foi a pressão pelo "choque neoliberal", o que desencadeou uma "guerra ideológica" em favor do corte de gastos públicos e da elevação dos juros como forma de combater a inflação. Essa pressão começou a surtir efeito já em 2013, com a retomada da alta dos juros em abril daquele ano ${ }^{24}$.

Assim, antes mesmo da deterioração dos indicadores econômicos, observa-se um sentimento difuso de insatisfação que precipita uma profunda alteração no contexto político e econômico. Junho de 2013 representa o ápice desse processo e constitui uma extraordinária oportunidade para os setores oposicionistas, à esquerda e à direita do espectro político, expressarem seu descontentamento com as políticas do governo.

Como vemos nos Gráficos 4 e 5, os protestos antecedem a crise. A curva ascendente dos protestos se deu em um contexto de desemprego em baixa e crescimento econômico positivo, a despeito das oscilações do PIB. Em 2011, as manchetes da Folha de S. Paulo apontavam para uma "desaceleração generalizada da economia", com queda do PIB de 7,6\% em 2010 para 3,9\% em 2011. Não obstante essa queda, o desemprego atingiu, entre 2012 e 2014, os indicadores mais baixos desde 2003, o que indica que a

24 Segundo o Banco Central, a média anual da taxa Selic caiu de 11,7\% em 2011 para 8,3\% em 2013 e voltou a $13,4 \%$ em 2015. 
redução do crescimento demorou a impactar o mercado de trabalho. Além disso, os trabalhadores sindicalmente organizados mantiveram conquistas econômicas importantes até 2014 , como revela o balanço das negociações coletivas feito pelo Dieese, que aponta o crescimento do percentual de acordos com reajustes superiores à inflação (Boito, Galvão e Marcelino, 2015) ${ }^{25}$.

\section{Associação entre protestos e PIB}

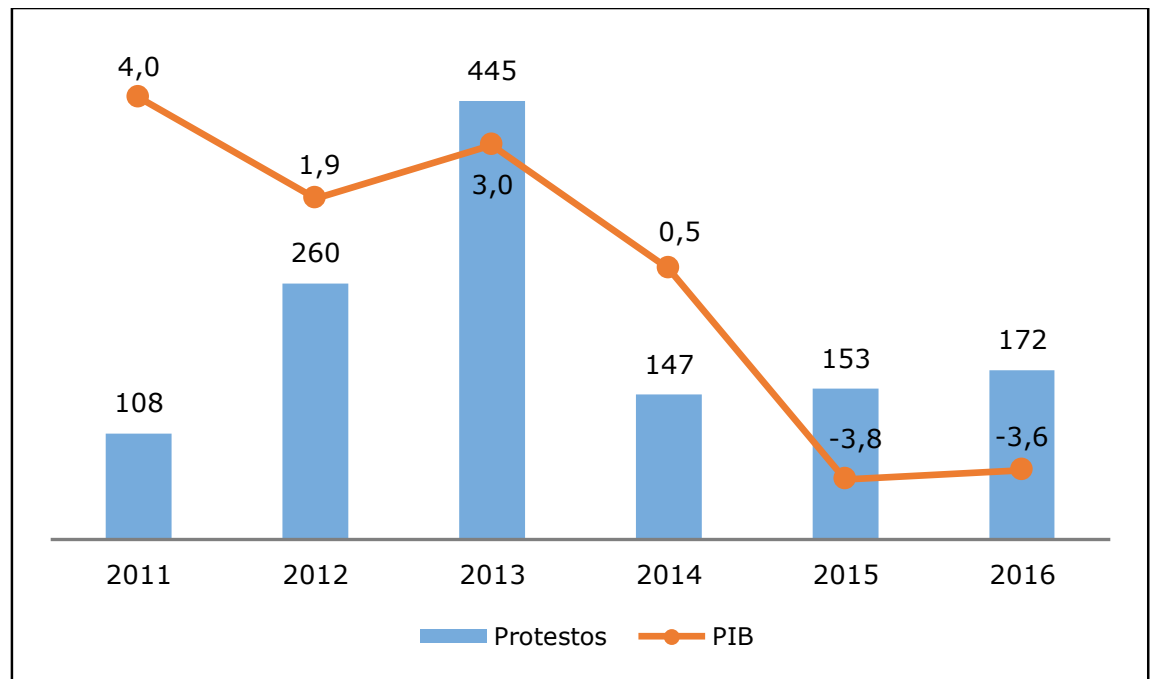

Fonte: Elaborado pelas autoras, a partir de dados do IBGE, Diretoria de Pesquisas, Coordenação de Contas Nacionais e Tatagiba e Galvão (2018).

\footnotetext{
${ }^{25}$ A inflação não registrou um aumento significativo até 2014. Segundo o IBGE, o IPCA acumulado anual passou de 6,5\% em 2011 para 5,91\% em 2013. A explosão inflacionária ocorreu em 2015, quando o IPCA alcançou $10,67 \%$.
} 


\section{Associação entre protestos e taxa de desocupação}

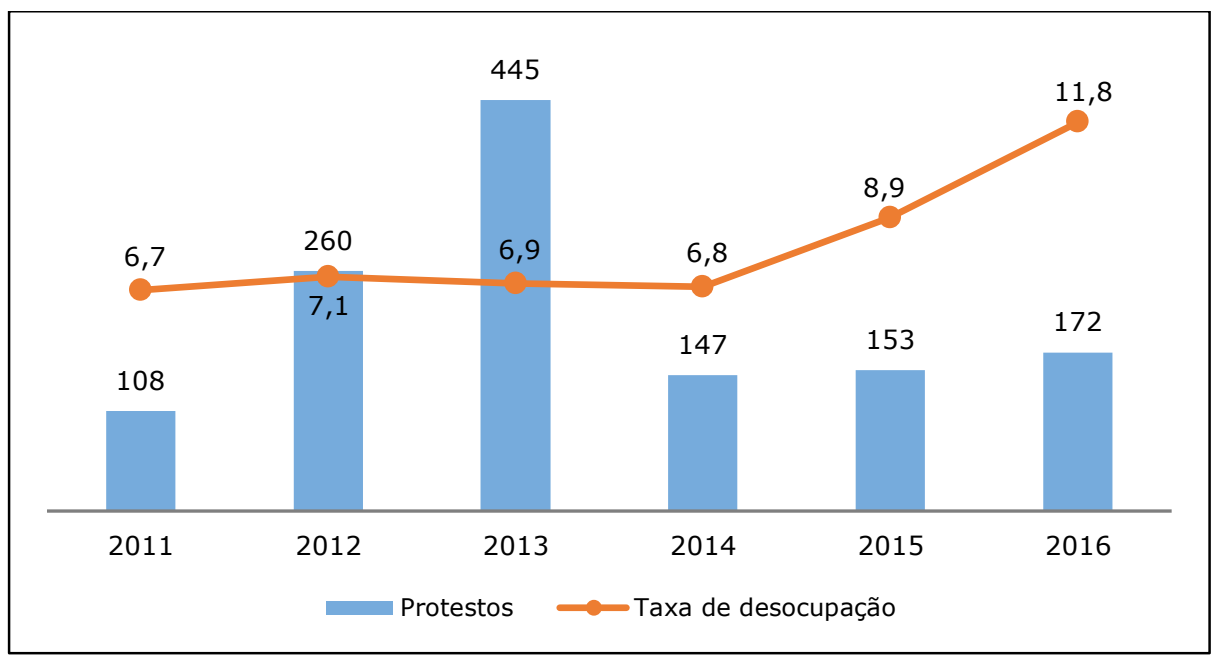

Fonte: Elaborado pelas autoras, a partir de dados do IBGE, da Pesquisa Nacional por Amostra de Domicílios Contínua e de Tatagiba e Galvão (2018).

Ou seja, os protestos crescem tanto num ano marcado por modesto crescimento econômico e baixo desemprego (2013) quanto naqueles marcados por recessão e desemprego elevado (2015-2016).

O pico dos protestos também antecede a queda da aprovação do governo, como mostra o Gráfico 6. O índice de aprovação do governo saltou de $48 \%$ em agosto de 2011 , para $62 \%$ em agosto de 2012 . Nesse mesmo período, os protestos cresceram $140 \%$. Após a massificação dos protestos, em junho de 2013, o governo foi lançado na defensiva: em março de 2013, o índice dos que consideravam o governo ótimo/bom era de $65 \%$, sua maior marca; no final de junho caiu para menos da metade, $30 \%$, oscilando para $36 \%$ em abril de 2014. No contexto da campanha pelo impeachment, a aprovação do governo atinge suas piores marcas com $13 \%(2015)$ e $10 \%(2016)^{26}$.

26 Disponível em: <http://media.folha.uol.com.br/datafolha/2016/04/11/avaliacao-presidente-dilma.pdf> Acesso em: 15 ago. 2018. 


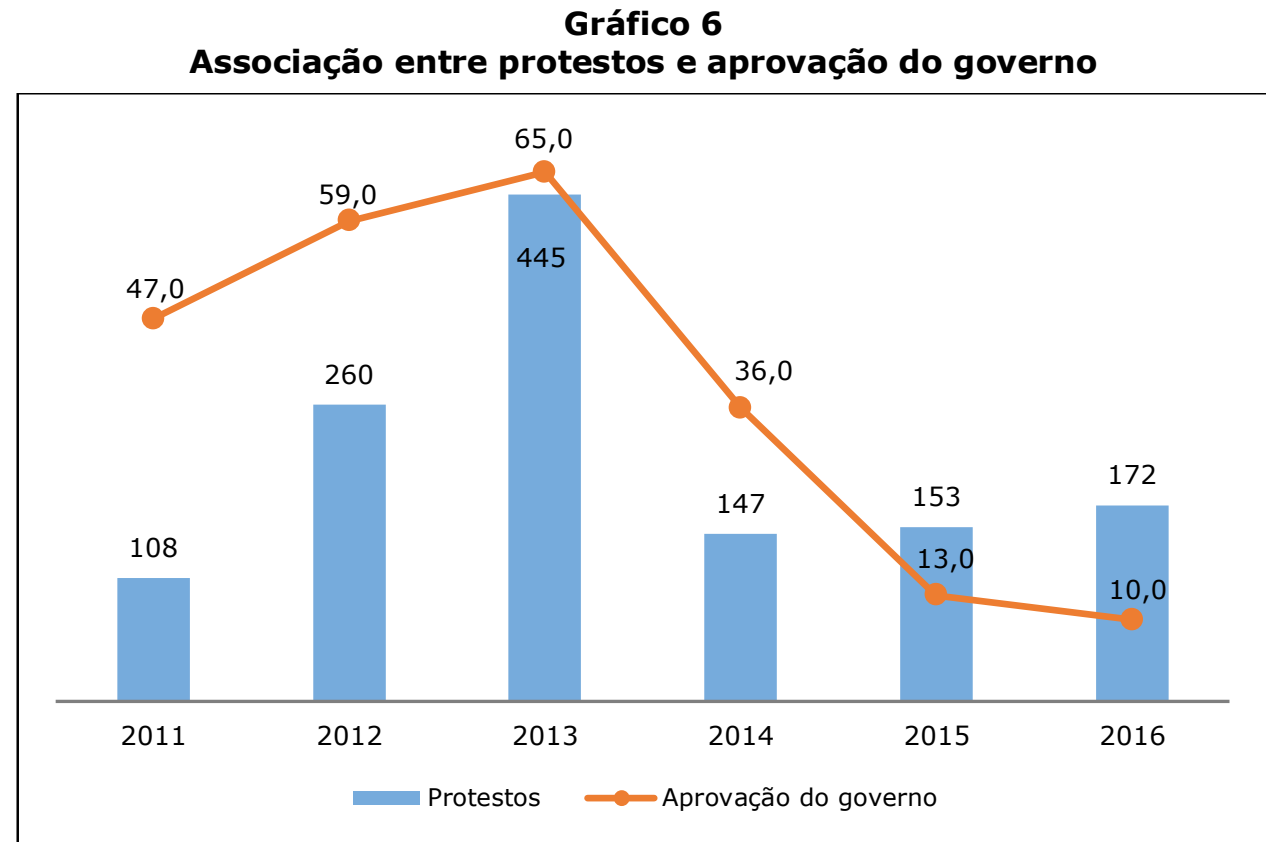

Fonte: Elaborado pelas autoras a partir de Tatagiba e Galvão (2018) e Datafolha.

Em síntese, não podemos considerar a emergência dos protestos como reflexo da deterioração das condições políticas e econômicas. Os dados parecem sugerir o contrário: os protestos, com trajetória ascendente desde 2012, se intensificam em 2013, abrindo espaço para a deterioração das condições políticas e econômicas e promovendo, ao mesmo tempo, um realinhamento da correlação de forças. É nesse sentido que argumentamos que os protestos expressam, em parte, as contradições dos governos petistas, ao mesmo tempo em que contribuem para produzir e aprofundar sua crise. A crise, por sua vez, potencializa os descontentamentos com o governo e fomenta novos protestos.

As políticas públicas implementadas pelos governos petistas afetaram, material e ideologicamente, as diferentes classes e grupos sociais. As políticas sociais feriram, direta ou indiretamente, a ideologia meritocrática, isto é, a crença de que o sucesso se deve ao esforço e aos méritos individuais, geralmente associados à trajetória escolar e à obtenção de um diploma. A reserva de vagas nas universidades públicas para alunos oriundos de escolas públicas e as cotas raciais para ingresso nas universidades e concursos públicos representaram uma ameaça aos padrões de distinção social caros às classes médias, reduzindo suas possibilidades de mobilidade social ascendente (Cavalcante, 2015; SaadFilho e Boito, 2016) ${ }^{27}$. Além das cotas, foram alvo de críticas crescentes os programas

27 Conforme esses autores, isso ajuda a explicar a centralidade da crítica à corrupção nos protestos das classes médias. Ao desviar recursos públicos, a corrupção não apenas prejudica o acesso a serviços públicos e sua qualidade, como também afeta as oportunidades de emprego típicas de classe média, que deixam de ser oferecidas pelo Estado. 
Bolsa Família, Minha Casa Minha Vida, Mais Médicos, a extensão dos direitos trabalhistas às empregadas domésticas, entre outros ${ }^{28}$. Assim, por limitadas que fossem, as conquistas dos subalternos provocaram descontentamentos e tensões com as classes médias e dominantes (Cavalcante, 2015; Singer e Loureiro, 2016), o que contribuiu para fomentar o antipetismo ${ }^{29}$ e a emergência das novas direitas.

A insatisfação dos setores médios e dominantes, que já aparece nas mobilizações de junho de 2013, ganha direção unificada na campanha eleitoral de 2014 e se fortalece com a operação Lava Jato ${ }^{30}$, desencadeada pela Polícia Federal e pelo Judiciário. O neoliberalismo ressurge com força nesse período e, com ele, a defesa do mercado em detrimento do Estado. O acirramento dos conflitos entre as classes pela apropriação de parcelas maiores da renda gerada na economia aumentou a pressão patronal pela redução do custo do trabalho e o combate ao pleno emprego (Bastos, 2017). Ao mesmo tempo, a difusão da teologia da prosperidade valorizou o empreendedorismo e o esforço individual (Almeida, 2017), o que dificultou o reconhecimento do papel do Estado - e das políticas públicas - no combate às desigualdades e à pobreza. O espraiamento das doutrinas neopentecostais reforçou discursos conservadores, tanto no plano moral e comportamental (concepção de família, direitos sexuais e reprodutivos) quanto no plano sociopolítico (com destaque para a escola sem partido e a redução da maioridade penal). A temática da corrupção ganhou força, sendo relacionada ao atributo moral dos políticos, especificamente, os do PT. As novas direitas passam a disputar as ruas, envolvendo grupos que combinam princípios e valores conservadores de modo distinto, mas que têm no antipetismo seu traço comum.

Como indicamos nesta seção, a forma como cada ator se posicionou na crise foi variada. Alguns grupos se fortaleceram, enquanto outros perderam protagonismo. Veremos, a seguir, como isso aparece em nosso banco de dados.

\section{Quem protesta?}

Como vemos no Gráfico 7, os grupos sociais tradicionalmente mobilizados são os que mais se fizeram presentes nas ruas entre 2011 e 2016, a exemplo dos trabalhadores (31\%), o que indica que o conflito entre capital e trabalho continua ativo na geração dos

\footnotetext{
28 A desvalorização do Real também contribuiu para a insatisfação das classes médias, na medida em que encareceu as importações e as viagens ao exterior. A média da taxa de câmbio passou de 1,67 R\$/US\$ em 2011 para 2,16 R\$/US\$ em 2013 e 3,34 R\$/US\$ em 2015, segundo dados do Banco Central.

29 "O antipetismo tem uma dupla face: por um lado, é um fenômeno político-eleitoral que integra o que se convencionou chamar de negative partisanship, a rejeição exclusiva a um partido; por outro lado, é um fenômeno sociopolítico que se expressa no ódio ao PT. (...) Esse envolvimento afetivo com a causa conferiu contornos particulares ao protesto, com imagens de manifestantes mordendo ou queimando bandeiras do PT, ou levando cartazes com imagens dos ex-presidentes decapitados ou enforcados. (...) Essa disposição cognitiva e emocional teve importantes implicações para o recrutamento e para as características da mobilização social no contexto da campanha pelo impeachment, que assumiu a forma de uma cruzada moral, representada na luta do bem (o "nós") contra o mal ("eles")" (Tatagiba, 2018).

30 Para a relação entre a dinâmica dos protestos e a condução da Operação Lava Jato, ver Tatagiba (2018).
} 
protestos. Em seguida está a categoria populares e moradores (19\%), que abarca grupos vinculados a associações de moradores, organizações de sem-terra e sem-teto (como o Movimento dos Trabalhadores Sem Terra, MST, e o Movimento dos Trabalhadores Sem Teto, MTST), movimentos comunitários por melhoria nos serviços públicos e frentes que articulam diferentes movimentos.

Conforme o Gráfico 8, dentre os trabalhadores mais mobilizados, destacam-se os dos setores da educação, indústria, comércio e serviço, geralmente representados por seus sindicatos, seguidos pela reunião de diferentes categorias profissionais, convocadas por centrais sindicais. Em quinta posição aparecem as forças de segurança, que se mobilizam sobretudo por intermédio de seus familiares, devido aos obstáculos legais à sindicalização e greve nesses setores. Os trabalhadores mais precários, como os informais, não se destacam entre aqueles que mais se mobilizam.

\section{Gráfico 7 \\ Grupos sociais (\%)}

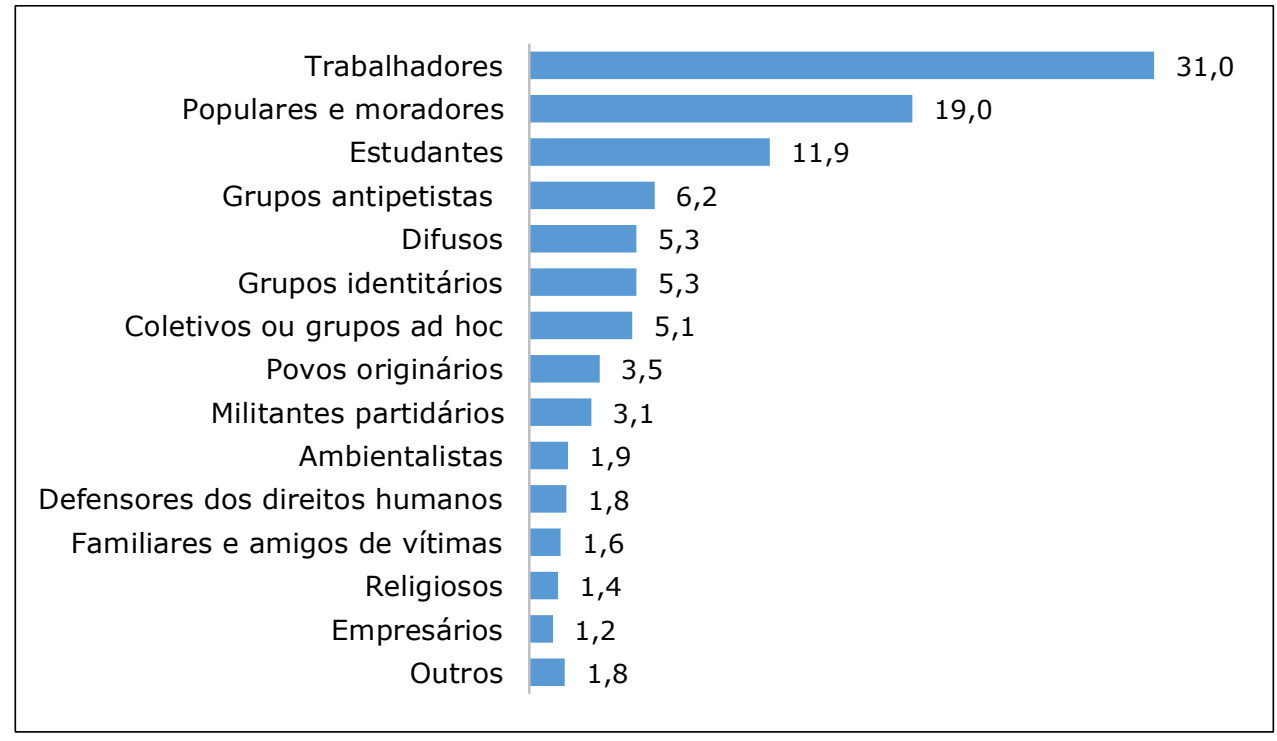

Fonte: Elaborado pelas autoras a partir de Tatagiba e Galvão (2018).

* Variável múltipla $(\mathrm{N}=1.469)$. 


\section{Gráfico 8 \\ Grupo social desagregado - Trabalhadores (\%)}

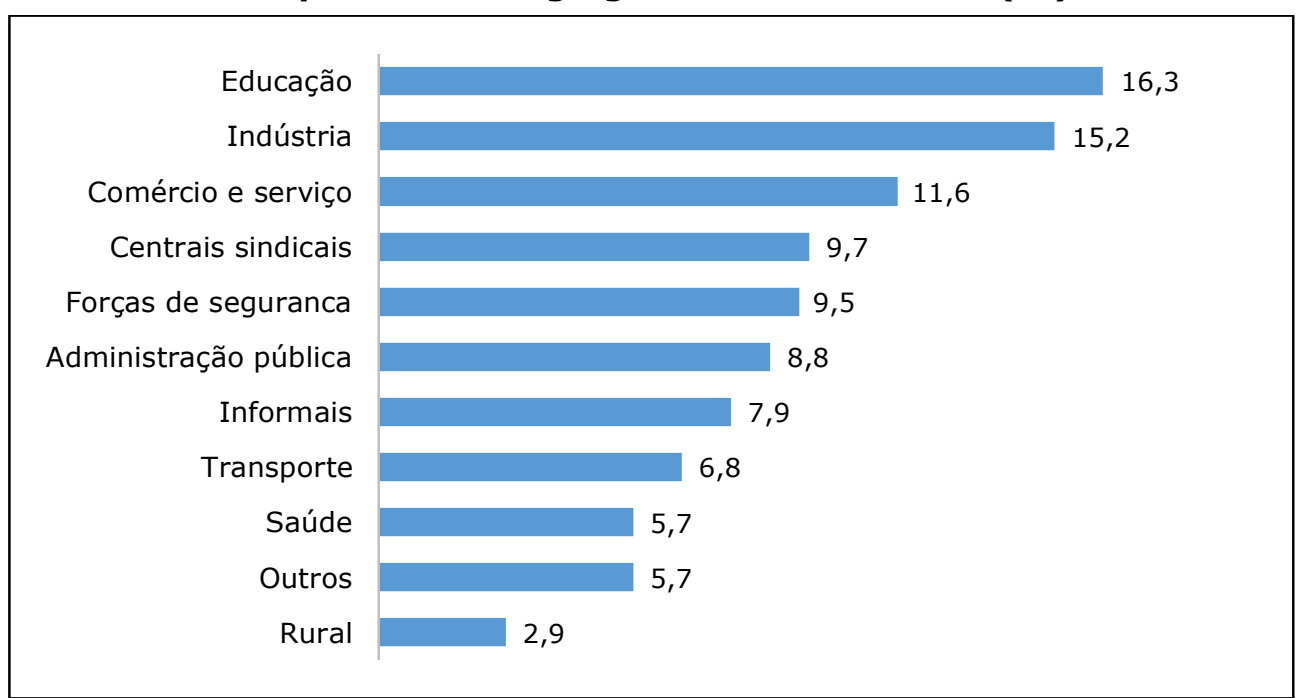

Fonte: Elaborado pelas autoras a partir de Tatagiba e Galvão (2018).

*Desagregação da categoria Trabalhadores $(\mathrm{N}=455)$.

Por outro lado, voltando ao Gráfico 7, a categoria populares compreende majoritariamente um contingente de trabalhadores pobres, precários, desempregados, que vivem de bico ou na informalidade. Nesse sentido, os protestos são protagonizados tanto por uma parcela da classe trabalhadora mais precária quanto por assalariados de classe média, como os da educação, bancários (inseridos no setor de serviços) e da administração pública, setores que se destacam pela taxa de sindicalização acima da média nacional e elevada atividade grevista.

Juntas, as categorias trabalhadores e populares representam $50 \%$ dos grupos sociais que protestaram no período. No interior das duas categorias, identificamos a presença de organizações formais, com densa capilaridade social e histórico de mobilização que remonta ao período de redemocratização, como a CUT e o MST, e o crescimento de novas organizações, como o MTST a partir de 2013. Trabalhadores não protestam apenas quando convocados por sindicatos e centrais, nem em nome de demandas exclusivamente trabalhistas, como podemos observar na Tabela 1. Além disso, protagonizam ações conjuntas com outros grupos sociais. Apesar de suas insatisfações com o governo, com o agravamento da crise política em 2015, trabalhadores e populares, articulados na Frente Brasil Popular e na Frente Povo sem Medo, coordenadas pelo MST e MTST, respectivamente, com a participação de centrais sindicais e partidos, saíram às ruas em defesa de direitos sociais e contra o impeachment. 
Tabela 1

Associação entre grupos sociais e reivindicações (\%)

\begin{tabular}{|l|c|c|c|c|c|}
\hline Grupo social & \multicolumn{5}{|c|}{ Reivindicações } \\
\hline Trabalhadores & Salário... & Governo... & Pol. econ. & Pol. sociais & Cond. de vida... \\
\hline & 48,5 & 15,7 & 11,3 & 9,5 & 6,8 \\
\hline Populares & Cond. de vida... & Governo... & Justiça... & Terra & M. ambiente... \\
\hline & 40,5 & 17,0 & 14,1 & 8,2 & 6,2 \\
\hline Estudantes & Cond. de vida & Pol. sociais & Governo... & Justiça... & Salário \\
\hline & 27,2 & 25,2 & 24,8 & 6,4 & 5,4 \\
\hline Antipetistas & Governo $\ldots$ & Justiça... & Pol. econ & Pol. sociais & Outros \\
\hline & 95,0 & 2,1 & 1,1 & 1,1 & 1,1 \\
\hline Difusos & Governo $\ldots$ & Pol. econ. & Justiça... & M. ambiente... & Outros \\
\hline & 63,1 & 13,8 & 6,2 & 4,6 & 3,1 \\
\hline
\end{tabular}

Fonte: Elaborado pelas autoras.

* As reivindicações são detalhadas na seção "Queixas e reivindicações" do artigo, p. 85. Aqui, para facilitar a exposição, usamos as categorias abreviadas.

Na terceira posição entre os grupos sociais que mais protestam estão os estudantes $(11,9 \%)$, cuja atuação no período se destacou por terem sido os madrugadores do pico de mobilização de 2013, com protestos contra o aumento das tarifas dos transportes públicos ainda em 2011, bem como pela campanha dos secundaristas contra as propostas de reformulação do ensino médio, em 2015 e 2016. Os estudantes também são um grupo social historicamente mobilizado no Brasil, tendo se destacado na luta contra a ditadura e nos episódios de confronto que culminaram no impeachment de Collor, em 1992. As organizações de representação estudantil tradicionais, como a UNE, continuam presentes na convocação dos protestos, ao lado da emergência de movimentos criados ao longo dos governos petistas, como o Movimento Passe Livre, e outros grupos autonomistas (Campos, Medeiros e Ribeiro, 2016; Campos e Teixeira, 2019). Como vemos na Tabela 1, os estudantes se mobilizaram em torno de um conjunto muito diverso de reivindicações.

Na quarta posição estão os grupos antipetistas (6,2\%), uma das grandes novidades do ativismo social nesse período ${ }^{31}$, responsável por ativar os mecanismos de polarização política. A Tabela 1 mostra que 95\% das reivindicações desse grupo referem-se ao funcionamento da própria democracia (categoria governo e sistema político). Esse é um grupo que não possui tradição de participação em protestos, mas que assumiu protagonismo no confronto ao tomar para si a bandeira da luta contra a corrupção, produzindo protestos massivos a partir de 2015 contra o governo Rousseff e o PT. Cumpre destacar que as pesquisas de opinião que traçaram o perfil dos manifestantes em prol do impeachment identificaram um predomínio de classe média, especificamente, a alta classe

31 Esse grupo corresponde ao que Alonso e Mische (2015) definem como "patrióticos". 
média (Datafolha, 2015a e 2015b; Fundação Perseu Abramo, 2016; Cavalcante, 2015; Arias e Cavalcante, 2019). A convocação dos protestos foi assumida por organizações como o MBL, Vem Pra Rua, Revoltados Online, Nas Ruas, Movimento Contra a Corrupção, entre outras organizações menores, a partir de um forte uso das redes sociais (Zanine e Tatagiba, 2019; Dias, 2017). Embora a maioria dessas organizações tenha surgido no contexto de 2013, os grupos antipetistas já estão presentes em protestos organizados em 2011, mantendo a mesma estética e slogans que caracterizaram sua atuação nos anos de 2015 e 2016, nos protestos convocados em defesa do impeachment de Rousseff (Tatagiba, Trindade e Teixeira, 2015; Tatagiba, 2018, 2019).

$\mathrm{Na}$ quinta posição encontram-se o que denominamos grupos sociais difusos $(5,3 \%)$, cujos protestos não permitem distinguir quem está na rua, seja porque as informações oferecidas pela FSP são insuficientes para derivar a(s) categoria(s) social(is) que protesta $(\mathrm{m})$, seja porque os participantes parecem ocupar o espaço público na condição de indivíduos desorganizados. Esse foi um caso comum nos protestos de 2013 após a revogação do aumento da tarifa do transporte público, em que era impossível definir quem estava na rua e que pautas defendiam. A FSP tampouco nos oferece informações relativas a renda, escolaridade, ocupação e cor dos manifestantes, o que poderia nos auxiliar na identificação aproximada da condição de classe desses grupos. De todo modo, as informações coletadas pelo Datafolha, e sistematizadas em Singer (2013), permitemnos inferir que esse grupo corresponde àquilo que Della Porta (2015) denomina cross class.

Na categoria grupos identitários (5,3\%) estão incluídos mulheres, LGBTs, negros e imigrantes. Os protestos das mulheres representam $69 \%$ do total. Os protestos ganharam maior visibilidade em 2015 com a campanha \#MulheresContraCunha, contra o PL 5.069, de autoria do então presidente da Câmara Eduardo Cunha, que dificultava o atendimento às mulheres vítimas de violência sexual, e a Primavera das Mulheres, por ocasião das comemorações de 8 de março em 2015/2016. Contudo, já em 2012 e 2013, o banco mostra significativo crescimento dos protestos de mulheres ${ }^{32}$ em consonância com os estudos que apontam a emergência de um novo ativismo feminista no Brasil, com a chegada da Marcha das Vadias em 2011 e um grande número de organizações feministas informais e autônomas (Alvarez, 2014; Gomes e Sorj, 2014; Medeiros e Fanti, 2019), em luta contra o machismo, o assédio, a violência e por direitos sexuais e reprodutivos. Os protestos LGBTs estão concentrados em 2011 e 2012 e foram motivados pelos debates no STF em torno da legalização da união civil entre pessoas do mesmo sexo e no confronto com os setores religiosos em razão das políticas contra a homofobia encampadas pelo MEC. Nosso banco identificou poucos protestos protagonizados pelos negros, dentre os quais a Marcha das Mulheres Negras, em 2015.

32 A evolução anual dos protestos de mulheres apresenta o seguinte comportamento: 5,6\% (2011), 22,2\% (2012), 29,6\% (2013), 3,7\% (2014), 18,5\% (2015) e 20,4\% (2016). N=54. 
Na sétima posição estão os coletivos ou grupos ad hoc $(5,1 \%)$. Incluímos nessa categoria grupos que se autodefinem como coletivos (p. ex., a Marcha da Maconha) - em distinção à forma movimento social ou organização - e aqueles que se juntam para responder a determinados eventos, dispersando-se quando as razões que motivaram a ação deixam de existir. Estão incluídos nessa categoria os coletivos de luta contra a Copa do Mundo e as Olimpíadas e os "Ocupas", que se tornaram populares a partir de 2013, como o "Ocupa Cabral", "Ocupa Tudo RS", "Ocupa Estelita", ou grupos como Anonymus e Black Blocs. Junto com os grupos antipetistas, os coletivos respondem por algumas das inovações do ativismo nesse período. Na sequência está a categoria povos originários $(3,5 \%)$, agregando indígenas, que representam mais de $80 \%$ do total, e quilombolas. Os protestos indígenas ganham notoriedade em 2013 e dizem respeito, principalmente, à demarcação de terras e à construção de hidrelétricas. Por fim, destacamos do Gráfico 7 a participação de religiosos $(1,4 \%)$, que protestaram contra o aborto, as políticas de proteção aos direitos LGBTs, a descriminalização das drogas e a corrupção. Incluímos nessa categoria as Marchas para Jesus, pois são eventos que se voltam a defender valores e disputá-los na sociedade, na perspectiva de um contramovimento.

Analisamos também os impactos da campanha de junho de 2013 sobre a participação nos protestos. Para isso, excluímos da análise o período entre 6/6/2013 (data do primeiro protesto contra a tarifa) e 20/6/2013 (quando se dá a retirada do MPL das ruas, após a revogação do aumento) e comparamos o comportamento dos grupos sociais antes e depois da campanha. Os resultados, apresentados na Tabela 2, sugerem que a campanha alterou a posição relativa dos grupos sociais, mas que a direção das mudanças está longe de ser unívoca. 
Tabela 2

Comparação dos grupos sociais nos protestos pré (T1) e pós (T2) junho de 2013

\begin{tabular}{|c|c|c|c|}
\hline Grupos Sociais & T1 & Grupos Sociais 2 & T2 \\
\hline Trabalhadores & 189 & Trabalhadores & 259 \\
\hline Populares e moradores & 89 & Populares e moradores & 186 \\
\hline Estudantes & 50 & Estudantes & 112 \\
\hline Grupos identitários & 34 & Grupos antipetistas & 74 \\
\hline Povos originários & 23 & Difusos & 62 \\
\hline Defensores dos direitos humanos & 19 & Coletivos ou grupos ad hoc & 54 \\
\hline Coletivos ou grupos ad hoc & 18 & Grupos identitários & 44 \\
\hline Grupos antipetistas & 17 & Militantes partidários & 31 \\
\hline Ambientalistas & 15 & Povos originários & 23 \\
\hline Difusos & 15 & Ambientalistas & 13 \\
\hline Familiares e amigos de vítimas & 14 & Religiosos & 9 \\
\hline Militantes partidários & 12 & Defensores dos direitos humanos & 8 \\
\hline Religiosos & 12 & Familiares e amigos de vítimas & 8 \\
\hline Empresários & 10 & Empresários & 5 \\
\hline Outros & 7 & Outros & 19 \\
\hline
\end{tabular}

Fonte: Elaborado pelas autoras a partir de Tatagiba e Galvão (2018).

* Variável múltipla $(\mathrm{N}=1393)$, sendo $\mathrm{T} 1<6 / 6 / 2013$ e T2 > 20/6/2013.

Sobre T1, chama a atenção o perfil dos grupos que ocupam as primeiras posições na Tabela 2: trabalhadores, populares/moradores, estudantes, grupos identitários, povos originários e defensores de direitos humanos. Os protestos parecem ter sido promovidos por setores progressistas vinculados à defesa de direitos, aliados do governo petista ou compondo uma oposição à esquerda, o que reforça o argumento dos contraditórios legados do lulismo como motor do confronto político no período. Em T2, vemos que os trabalhadores, populares/moradores e estudantes não apenas mantiveram as primeiras posições, como também ampliaram sua participação nos protestos. No caso dos grupos identitários, a perda do peso relativo veio acompanhada do aumento do número de protestos, principalmente das mulheres, que tiveram participação destacada nas ruas. Mas a principal novidade foi o deslocamento dos grupos antipetistas (da oitava para a quarta posição) e dos grupos sociais difusos (da décima para a quinta posição). Os protestos de junho de 2013 parecem ter produzido mudanças no contexto político, o qual, por sua vez, impactou a dinâmica do ativismo em duas direções principais: fortalecimento dos setores oposicionistas à direita e estímulo à participação de indivíduos não organizados.

O crescimento dos grupos antipetistas e difusos evidencia a composição heterogênea das Jornadas de Junho, de modo que não é possível identificar naqueles protestos o predomínio do precariado - entendido, nos termos de Braga (2013), como parcela da classe trabalhadora -, parecendo-nos mais plausível a hipótese de Singer (2013, p. 27), que aponta a coexistência de trabalhadores e classe média, protestando por motivos variados. 


\section{Queixas e reivindicações}

A análise das reivindicações evidencia o padrão de mobilização social nesse período, marcado pela combinação entre uma crescente polarização em torno do eixo PT $X$ anti-PT combinado a sentimentos de insatisfação que se estendem sobre diversos temas. O Gráfico 9 mostra que foram três grandes conjuntos de problemas que motivaram os protestos: governo e sistema político $(25,2 \%)$, salário e condições de trabalho $(17,6 \%)$ e condições de vida nas cidades (16,5\%). A categoria governo e sistema político abrange principalmente pautas relativas ao funcionamento da democracia e ao antipetismo. A categoria salário e condições de trabalho expressa o conflito distributivo e os limites da capacidade de os governos petistas incorporarem as demandas dos trabalhadores. Por fim, a categoria condições de vida nas cidades reflete a forma como as experiências cotidianas de privação atuaram no confronto, especialmente no que se refere ao tema do transporte público e da moradia, demandas que expressam forte associação com a experiência de classe dos trabalhadores, principalmente os mais precarizados ${ }^{33}$.

Gráfico 9

Reivindicações (\%)

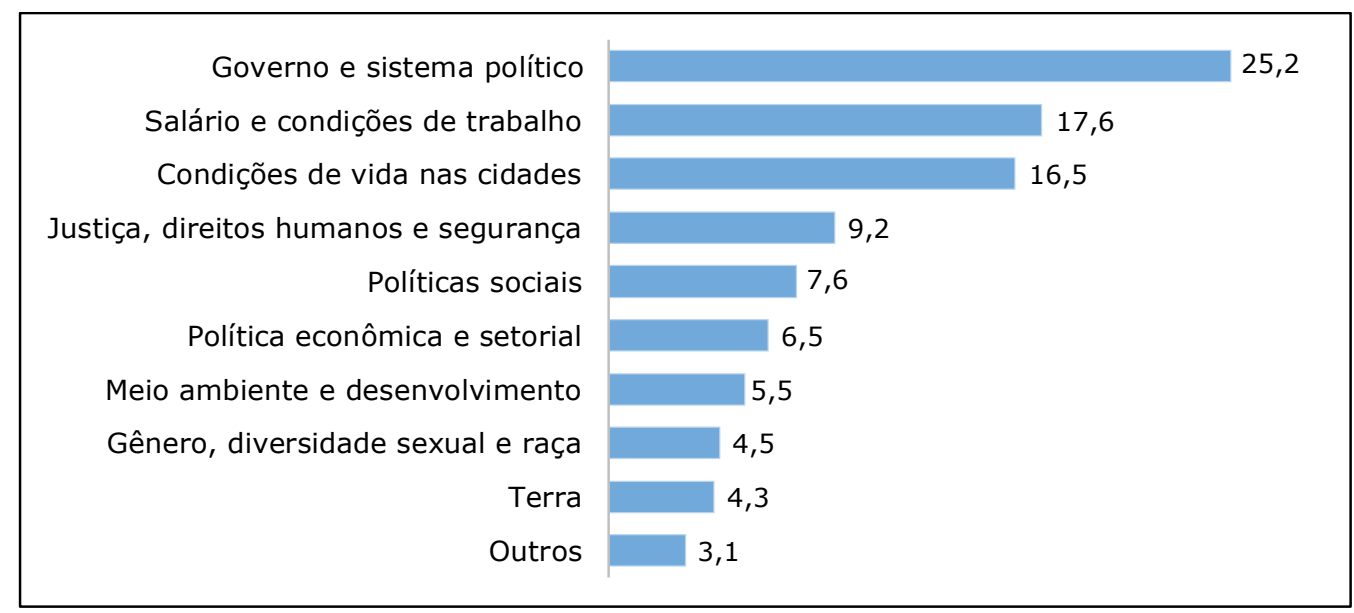

Fonte: Elaborado pelas autoras a partir de Tatagiba e Galvão (2018).

* Variável múltipla $(\mathrm{N}=1373)$. Missing 57 eventos, correspondendo a 3,9\% do total.

\footnotetext{
33 Agradecemos ao colega Marcelo Kunrath Silva por ter chamado nossa atenção para a forma como a relação entre "condições de vida" e protesto permeou a produção brasileira, principalmente a partir do trabalho de Sader (1995), que mostra como as matrizes discursivas mobilizadoras da Teologia da Libertação e do Novo Sindicalismo dialogavam com a experiência de determinadas condições de classe. Essa é uma tradição de análise que merece ser revisitada.
} 
Governo e sistema político (25,2\%) compreende protestos contra políticos ${ }^{34}$ e governos dos mais variados matizes político-partidários (48,4\% do total da categoria), contra ou a favor do impeachment de Rousseff (17,4\% da categoria), contra a corrupção (14,2\% da categoria), em apoio ou crítica ao funcionamento de instituições políticas específicas como a Polícia Militar, a Polícia Federal, o STF, partidos políticos $(6,7 \%$ da categoria), em defesa da liberdade de expressão e mobilização (5,6\% da categoria), protestos em apoio à democracia ou à ditadura ${ }^{35}(5,6 \%$ da categoria) e pela regulamentação dos meios de comunicação ( $2,1 \%$ da categoria).

Gráfico 10

Evolução das principais reivindicações (\%)

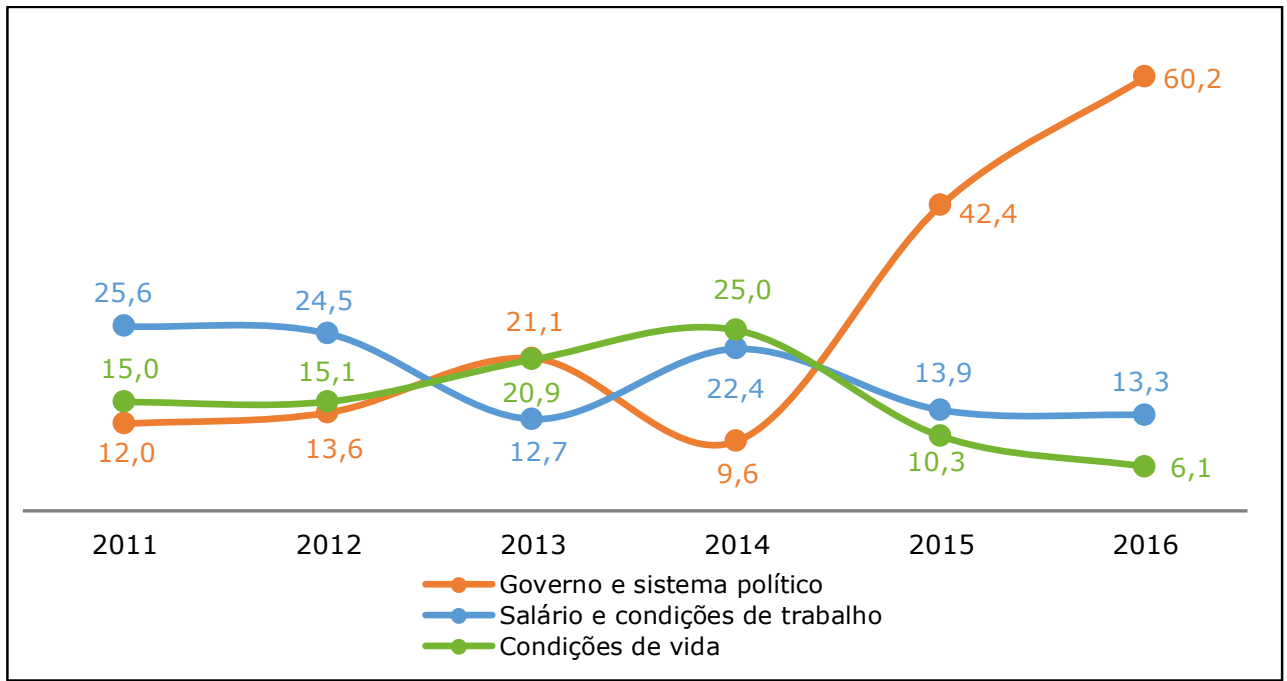

Fonte: Elaborado pelas autoras a partir de Tatagiba e Galvão (2018).

* Variável múltipla $(\mathrm{N}=813)$, correspondendo a $59,2 \%$ do total.

Como vemos no Gráfico 10, as reivindicações envolvendo governo e sistema político já estão presentes em 2011, embora em um número pequeno de protestos. Essas reivindicações crescem em 2013, mas é apenas a partir de 2015 que se tornam majoritárias na agenda pública, atingindo em 2016, no auge da crise política, $60 \%$ do total

\footnotetext{
34 Figuram na lista, para além das personalidades petistas, Geraldo Alckmin, Sérgio Cabral, Eduardo Paes, Roberto Richa, Gilberto Kassab, Renan Calheiros, Eduardo Cunha, Marco Feliciano, Michel Temer e seus ministros.

35 O principal evento que detona esses conflitos é a instalação da Comissão da Verdade, em 16 de maio de 2012, que gerou episódios de confronto entre opositores e apoiadores da ditadura militar de 1964. Embora não sejam numericamente relevantes, eles importam na medida em que recolocam em discussão os consensos em torno da democracia. Esses protestos não tiveram número grande de participantes e foram concentrados em São Paulo, Brasília e Rio de Janeiro, sendo que este último abrigou o maior número de atos. Um evento repleto de simbolismo foi a II Marcha da Família com Deus pela Liberdade, realizada em 22/3/2014, que celebrou 50 anos do golpe militar, levando 700 pessoas às ruas (segundo a PM) em São Paulo e 150 no Rio Janeiro.
} 
dos protestos. Essa é uma pista que precisa ser mais bem trabalhada, mas o germe de insatisfação com os políticos identificado a partir de 2011 é canalizado pela direita em 2014, quando Aécio Neves contesta o resultado da eleição. É nesse momento que as críticas difusas à corrupção e ao funcionamento da democracia representativa convergem para o antipetismo.

Podemos mensurar o antipetismo isolando os protestos da categoria governo $e$ sistema político que tiveram como alvo o governo federal, Lula, o PT ou lideranças do PT e que mantiveram uma estética e uma narrativa alinhadas com o que vimos nas ruas em 2015 e 2016 (cf. Gráfico 11).

Gráfico 11

\section{Evolução anual do antipetismo (\%)}

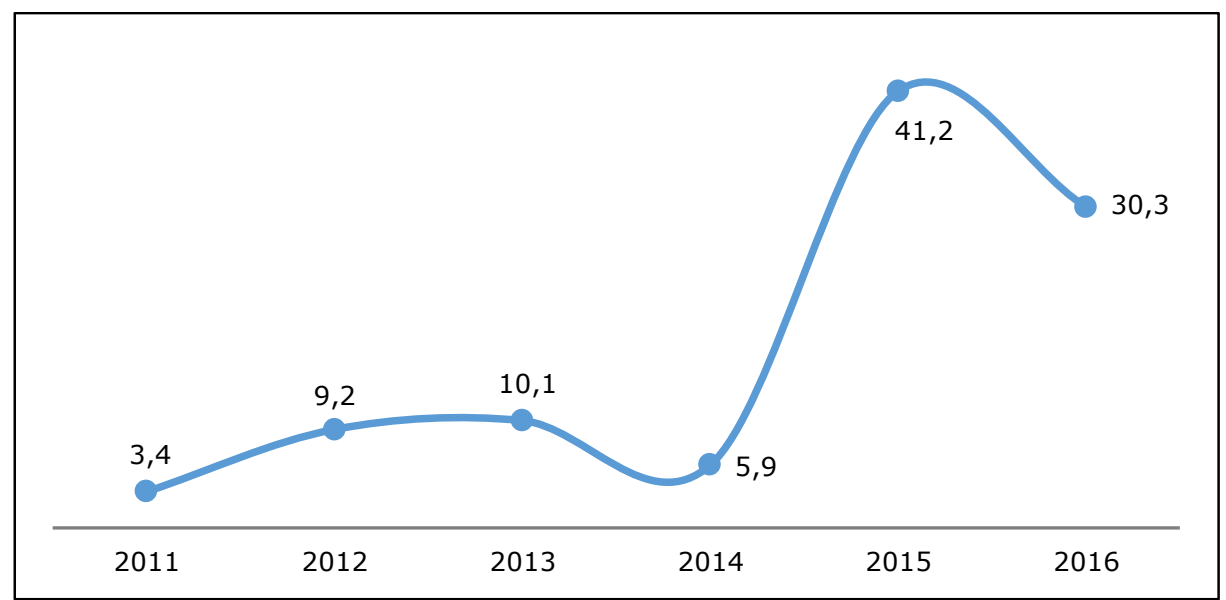

Fonte: Elaborado pelas autoras a partir de Tatagiba e Galvão (2018).

* $\mathrm{N}=121$, corresponde a $32,4 \%$ da categoria governo e sistema político.

Assim, é importante considerar que o descrédito na política e nos políticos é maior do que o antipetismo (cf. Gráfico 11) e anterior a 2013 (cf. Gráfico 11 e Tabela 3), mas foram os grupos oposicionistas à direita que conseguiram traduzir esse sentimento, associando-o à corrupção dos governos petistas. O êxito dos oposicionistas em reconstruírem o terreno simbólico do confronto fica evidente na mudança da opinião pública: pesquisa divulgada pelo Datafolha em novembro de 2015 aponta que, pela primeira vez, a corrupção foi eleita como principal problema pelos brasileiros (para 34\% dos entrevistados), deixando para trás temas tradicionais, como saúde ( $16 \%$ das menções espontâneas), desemprego (8\%) e educação (8\%) (Datafolha, 2015).

As reivindicações envolvendo salário e condições de trabalho $(17,6 \%)$ ocupam a segunda posição no Gráfico 9. Contra aqueles que diziam que o trabalho deixou de ser uma categoria importante na ação coletiva nas sociedades contemporâneas, e que teria sido substituído por demandas pós-materiais, como as baseadas no reconhecimento de 
identidades, nosso banco de dados sugere o oposto. Em 2012, houve um forte ciclo de greves, principalmente junto ao funcionalismo público federal (com mais de 30 categorias em greve). As greves atingiram as universidades federais (41 das 59 instituições paralisaram suas atividades), que haviam passado por um processo de expansão, em defesa de salário, carreira e melhorias na educação. As greves também envolveram os trabalhadores da construção civil, com destaque para os trabalhadores das usinas hidrelétricas de Belo Monte, Jirau e Santo Antonio, que realizaram oito greves entre 2011 e 2013, os operários das obras dos estádios para a Copa do Mundo de Futebol de 2014, do Porto de Suape, dos canteiros petroquímicos do estado do Rio de Janeiro (Comperj). Por fim, registra-se a ocorrência de greves em setores de serviços mais precarizados, como os garis do Rio de Janeiro, que paralisaram suas atividades no carnaval de 2014 e obtiveram conquistas econômicas significativas já em um período de desaceleração da economia. Observe-se que muitas dessas greves foram deflagradas contra a direção dos sindicatos (Galvão, 2019).

A possibilidade de introdução de mudanças na legislação trabalhista também ensejou mobilizações importantes, convocadas por centrais sindicais e movimentos populares. A pressão patronal pela flexibilização de direitos estimulou a apresentação e a tramitação de projetos de lei visando à implementação de novas modalidades de contratação precária, à ampliação da terceirização, à revogação da lei pela negociação, à redução de benefícios da seguridade social e à restrição do acesso à aposentadoria. Apenas em 2015 foram convocadas três jornadas de luta contra a ampliação da terceirização e, até agosto de 2016, três dias nacionais de mobilização contra Temer e suas contrarreformas trabalhista e previdenciária (Galvão e Marcelino, 2019).

Na terceira posição do Gráfico 9 estão as reivindicações relativas às condições de vida nas cidades, que englobam os problemas relativos a moradia (peso na categoria $40 \%$ ), transporte (peso na categoria $38 \%$ ), política urbana (peso na categoria $14 \%$ ) $^{36} \mathrm{e}$ serviços públicos ${ }^{37}$ (peso na categoria de $9 \%$ ). Os problemas de moradia e de transporte assumiram centralidade nessa conjuntura, sendo que o segundo constitui o estopim das Jornadas de Junho de 2013. Os protestos envolvendo o preço e/ou a qualidade do transporte público já aparecem no nosso banco desde 2011, principalmente no Rio de Janeiro e em São Paulo, sendo que, em metade dos protestos, as cenas de confronto entre policiais e manifestantes lembram as imagens que se popularizam em junho de 2013 . As opções do governo federal para lidar com o déficit habitacional implicaram o aumento exponencial do preço da terra urbana, com o boom imobiliário entre 2009 e 2015. A pressão sobre a terra teve impactos diretos sobre o preço dos aluguéis e a mobilidade urbana, empurrando os pobres cada vez mais para a periferia. O contexto de realização

\footnotetext{
36 Trata-se quase exclusivamente das disputas envolvendo a legislação urbanística em São Paulo e a definição das áreas para o comércio informal.

37 Serviços públicos envolvem basicamente serviços de zeladoria, como troca de lâmpada, tapagem de bueiro, troca de semáforo, podas de árvores etc.
} 
dos megaeventos trouxe novas tensões a esse cenário, em face das constantes violações ao direito à moradia e à mobilidade nas cidades-sede. Esse contexto ampliou o poder de convocação dos movimentos por moradia e transporte, principalmente entre 2011 e 2014, resultando em vigorosas mobilizações que uniram vários grupos à esquerda do PT, muitos deles com inspiração autonomista. Em 2014, a moradia foi a principal reivindicação presente nos protestos, com destaque para as ocupações promovidas pelo MTST em São Paulo.

Na quarta posição, Justiça, direitos humanos e segurança $(16,5 \%)$ engloba demandas por esclarecimento de crimes, sejam eles cometidos pelo Estado ou por particulares $(78 \%)$ e demandas gerais por mais segurança e mudanças na política de segurança, incluindo o tema das drogas. Na sua maioria, os protestos envolvem queixas dos moradores de comunidades pobres contra abordagens violentas da polícia, morte de moradores por policiais, investigação de chacinas e, em menor número, denúncia de execução de ativistas de movimentos sociais. São atos, no geral, menos visíveis mas, em 2013, o arbítrio policial nas favelas do Rio de Janeiro ganhou espaço no debate público e nas ruas com a campanha Cadê Amarildo?, que articulou uma ampla rede de solidariedade em virtude do desaparecimento do pedreiro Amarildo, morador da comunidade da Rocinha, após sua detenção por policiais militares. As investigações comprovaram que Amarildo foi conduzido à UPP, onde foi torturado e assassinado. Outros dois casos que tiveram destaque no nosso banco foram a violenta reintegração de posse da ocupação Pinheirinho, em São José dos Campos (SP), e a ação da Polícia Militar na Cracolândia, ambos em 2012.

A quinta categoria, políticas sociais $(7,6 \%)$, traz as reivindicações por melhorias na educação (com peso de $72 \%$ na categoria) e saúde. Política econômica e setorial $(6,5 \%)$ abrange demandas relativas a política de juros, redução de impostos, privatização de portos e aeroportos, leilões de poços de petróleo, dentre outras. A categoria meio ambiente e desenvolvimento $(5,5 \%)$ inclui reivindicações em torno dos recursos naturais (com exceção da terra, que constitui uma categoria à parte), proteção ambiental, direitos dos animais, protestos contra a construção das hidrelétricas, a transposição do São Francisco e os megaeventos. A campanha Não Vai Ter Copa e a ocupação Copa do Povo sintetizam o esforço de conexão de lutas com movimentos por moradia e transporte. A categoria gênero, diversidade sexual e raça $(4,5 \%)$ compreende demandas relacionadas a machismo, violência contra a mulher, em defesa e contra o aborto e união civil entre pessoas do mesmo sexo. A questão LGBT suscita protestos tanto contra o kit antihomofobia, do Ministério da Educação, quanto contra a homofobia, em 2011. Ao longo de todo o período, cinco protestos tematizaram diretamente a questão racial, a maior parte deles a partir do debate acerca das cotas raciais nas universidades. A categoria terra $(4,0 \%)$ compreende demandas relativas à demarcação de terras indígenas, quilombolas, política de reforma agrária e política de assentamento. 
Analisamos também os impactos da campanha de junho de 2013 sobre as queixas e reivindicações apresentadas nos protestos. Para isso, repetimos na Tabela 3 o mesmo procedimento realizado para grupos sociais, ou seja, excluímos da análise o período entre 6/6/2013 e 20/6/2013 e comparamos T1 e T2.

Tabela 3

Comparação reivindicações pré (T1) e pós junho (T2) de 2013

\begin{tabular}{|c|c|c|c|}
\hline Reivindicações & T1 & Reivindicações & $\mathbf{T 2}$ \\
\hline Salário e condições de trabalho & 111 & Governo e sistema político & 270 \\
\hline Governo e sistema político & 73 & Condições de vida & 142 \\
\hline Condições de vida & 70 & Salário e condições de trabalho & 123 \\
\hline Justiça, direitos humanos e segurança & 64 & Políticas sociais & 70 \\
\hline Política econômica e setorial & 36 & Justiça, direitos humanos e segurança & 59 \\
\hline Gênero, diversidade sexual e raça & 35 & Política econômica e setorial & 52 \\
\hline Terra & 31 & Meio ambiente e desenvolvimento & 47 \\
\hline Políticas sociais & 31 & Sem dados & 36 \\
\hline Meio ambiente e desenvolvimento & 26 & Outros & 28 \\
\hline Sem dados & 19 & Terra & 25 \\
\hline Outros & 15 & Gênero, diversidade sexual e raça & 24 \\
\hline
\end{tabular}

Fonte: Elaborado pelas autoras a partir de Tatagiba e Galvão (2018).

* $\mathrm{T} 1<6 / 6 / 2013$ e $\mathrm{T} 2>20 / 6 / 2013(\mathrm{~N}=1.387)$.

A comparação mostra que as três principais categorias ocupam o topo da lista em T1 e T2, embora em posições distintas: em T2, governo e sistema político e condições de vida nas cidades assumem centralidade, e as demandas relativas a salário e trabalho passam para terceiro lugar. O principal deslocamento são as reivindicações em torno das políticas sociais, que sai da oitava para a quarta posição. Este é o primeiro desdobramento das Jornadas de Junho, a campanha dos secundaristas. Gênero, diversidade sexual e raça também se desloca, mas num sentido inverso, perdendo centralidade, embora a participação das mulheres tenha sido importante nas manifestações contra o impeachment.

\section{Considerações finais}

Este artigo mostra a complexa relação entre protestos e mudança social no conturbado período dos governos de Dilma Rousseff. Sustentamos que os protestos resultaram das mudanças produzidas pelos governos petistas, que geraram um conjunto diverso de insatisfações em diferentes grupos sociais, situados entre os dois polos do espectro político. Os protestos precedem a eclosão da crise econômica, ao mesmo tempo em que a intensificação dos protestos evidencia os limites da conciliação de classes. Nas 
ruas, esse processo se expressou em um padrão de mobilização social que combinou polarização política (em torno do eixo PT $x$ anti-PT) e heterogeneização de atores e reivindicações.

Nosso banco de dados corrobora achados da bibliografia, que apontam tanto a permanência dos conflitos de classe quanto o fortalecimento de conflitos estruturados em torno de outros pertencimentos identitários, especialmente os das chamadas minorias. Esses atores foram afetados de modo diferenciado pelas políticas implementadas pelos governos petistas, resistindo a seus avanços ou criticando seus limites. Enquanto certos segmentos de classe média (assalariados nos setores de educação e funcionários públicos) se uniram a trabalhadores precários e movimentos populares em defesa dos direitos e da democracia (como nas frentes contra o golpe), outros segmentos (profissionais liberais, assalariados de classe média em postos de gestão) tenderam a se somar aos setores dominantes para denunciar, de modo seletivo, a política dos governos petistas e sua corrupção. Assim, a conciliação de classes deu lugar a uma polarização política em torno do eixo PT $x$ anti-PT.

A curva de protestos entre 2011 e 2016 é marcada por oscilações, e os picos registrados em 2013 e 2015-2016 indicam mudanças na magnitude dos protestos. As principais reivindicações apresentadas no período revelam a descrença nas instituições políticas, a preocupação com direitos bem como com as condições materiais de existência: governo e sistema político; salário e condições de trabalho; e condições de vida nas cidades, sendo que a primeira delas parece ser a grande novidade, sobretudo após 2013.

Embora 2013 registre mudanças nos padrões do protesto no que se refere a seu volume e grau de conflitividade, as queixas apresentadas já motivavam lutas coletivas pelo menos desde 2011 e, em alguns casos, se desdobraram em vigorosas campanhas nos anos seguintes, o que nos permite problematizar a tese de que 2013 inaugura um novo ciclo. Do mesmo modo, consideramos que não há uma descontinuidade entre 2013 e 20152016: o pico das mobilizações em 2013 cria oportunidades políticas inéditas para os setores oposicionistas, à direita e à esquerda do PT, conformando um cenário de crise política que, associado à crise econômica, abre caminho para o impeachment.

Também no que se refere aos atores, observam-se mudanças e continuidades. Os grupos sociais mais ativos foram aqueles com histórico de mobilização: trabalhadores, populares (como os sem-teto e os sem-terra) e estudantes. Ao mesmo tempo, a maior abertura à participação dos movimentos sociais e sindicais no Estado ampliou a fragmentação no interior da esquerda organizada e os impactos do neodesenvolvimentismo sobre as populações tradicionais estimularam a contestação aos limites dos governos petistas e de sua política de conciliação de classes. Assim, destacamos a emergência de novos coletivos à esquerda e das novas direitas, que adquiriram visibilidade crescente nas ruas, fomentando o antipetismo e o conservadorismo. 
As classes trabalhadoras e populares tradicionalmente se mobilizam, mas a novidade do período foi o maior ativismo dos setores médios e dominantes. Logo, não é possível identificar uma tendência unívoca ao ativismo do precariado ou das classes médias durante os governos Rousseff. As duas classes mantêm um alto nível de mobilização, mobilização essa que se dá por motivos variados, que têm a ver com a maneira pela qual sofrem e percebem o impacto das mudanças socioeconômicas, políticas e culturais verificadas ao longo do período.

\section{Referências bibliográficas}

Abers, R.; Serafim, L.; TAtAgibA, L. "Repertórios de interação Estado-sociedade em um Estado heterogêneo: a experiência da era Lula". Dados, vol. 57, no 2, p. 325-357, 2014.

ABERS, R.; TATAGIBA, L. Institutional activism: mobilizing for women's health from inside the Brazilian bureaucracy. In: Von BULow, M., RosSI, F. (orgs.). Social movement dynamics. New perspectives in theory and research from Latin American. Canada: Ashgate, 2015.

ALmeIDA, R. "A onda quebrada - evangélicos e conservadorismo". Cadernos Pagu, nº 50, 2017.

Alonso, A.; MisCHE, A. "June demonstrations in Brazil: repertoires of contention and government's response to protest". 2015. Disponível em:

<https://www.academia.edu/11309520/June_demonstrations_in_Brazil_repertoires_of_contention_ and_government_s_response_to_protest>. Acesso em: 26 nov. 2016.

Alvarez, S. "Para além da sociedade civil: reflexões sobre o campo feminista". Cadernos Pagu, no 43, 2014.

ARIAS, S.; CAVALCANTE, S. A divisão da classe média na crise política brasileira (2015-2016). In: BOUfFARTIGUE, P., et al. (org.). O Brasil e a França na mundialização neoliberal: mudanças políticas e contestações sociais. São Paulo: Alameda, 2019.

BARKER, C., et al. (eds.). Marxism and social movements. Leiden/Boston: Brill, 2013.

BASTOS, P. P. "Ascensão e crise do governo Dilma Rousseff e o golpe de 2016: poder estrutural, contradição e ideologia". Revista de Economia Contemporânea, vol. 21, n 2, 2017.

Biroli, F.; MANTOVAni, D. "A parte que me cabe nesse julgamento: a Folha de S. Paulo na cobertura ao processo do Mensalão". Opinião Pública, vol. 20, n 2, p. 204-218, 2014.

BoITo, A. Governos Lula: a nova burguesia nacional no poder. In: BoITo, A.; GalVÃo, A. (orgs.). Política e classes sociais no Brasil dos anos 2000. São Paulo: Alameda/Fapesp, 2012.

Boito, A.; Galvão, A.; Marcelino, P. "La nouvelle phase du syndicalisme Brésilien". Cahiers des Amériques Latines, no 80, p. 147-167, 2015.

BRAGA, R. A política do precariado: do populismo à hegemonia lulista. São Paulo: Boitempo, 2012.

. Sob a sombra do precariado. In: HARVEY, D., et al. Cidades rebeldes. Passe livre e as manifestações que tomaram as ruas do Brasil. São Paulo: Boitempo, p. 79-82, 2013.

BRINGEL, B; PLEYERS, G. "Junho de 2013... Dois anos depois: polarização, impactos e reconfiguração do ativismo no Brasil". Nueva Sociedad: democracia e política en América Latina, volume especial em português, nov. 2015. 
CAmpos, A.; TeixeirA, A. C. C. "Occupy and resist": the autonomist imaginary in the new youth activism in Brazil. In: FerRero, J.; TATAgibA, L.; NATAlucCI, A. (eds.). Socio-political dynamics within the crisis of the left turn in Argentina and Brazil. Londres: Rowman and Littlefield, 2019.

Campos, A.; Medeiros, J.; Ribeiro, M. Escolas de luta. São Paulo: Veneta, 2016.

CAVA, B.; Cocco, G. (orgs.). Amanhã vai ser maior: o levante da multidão no ano que não terminou. São Paulo: Annablume, 2014.

Cavalcante, S. Classe média e conservadorismo liberal. In: CRuz, S. V.; KaYSel, A.; Codas, G. (orgs.). Direita, volver! O retorno da direita e o ciclo político brasileiro. São Paulo: Editora Fundação Perseu Abramo, p. 177-196, 2015.

DAGNINO, E. A transformação dos discursos e práticas na esquerda latino-americana. In: ALVAREZ, S. E.; DAGNINo, E.; ESCOBAR, A. Cultura e política nos movimentos sociais latino-americanos: novas leituras. Belo Horizonte: UFMG, p. 61-102, 2000.

DATAFOlHA. "Manifestação na Avenida Paulista", survey com participantes de 15/3/2015. 2015a. Disponível em: <http://datafolha.folha.uol.com.br/opiniaopublica/2015/03/1604284-47-foram-aavenida-paulista-em-15-de-marco-protestar-contra-a-corrupcao.shtml>. Acesso em: 5 abr. 2016.

. "Manifestação na Avenida Paulista", survey com participantes de 16/8/2015. 2015b. Disponível em: <http://datafolha.folha.uol.com.br/opiniaopublica/2015/08/1669735-135-mil-vao-aprotesto-na-paulista.shtml>. Acesso em: 2 mar. 2017.

. "Avaliação do governo Dilma Rousseff", 25-26/11/2015. 2015c. Disponível em: <http://media.folha.uol.com.br/datafolha/2015/11/30/avaliacao_dilma.pdf>. 2015. Acesso em: 5 abr. 2016.

DATALUTA. "Banco de dados da luta pela terra: relatório Brasil 2015". Nera, Unesp Presidente Prudente, 2016.

DELLA PORTA, D. Social movements in times of austerity: bringing capitalism back into protest analysis. Cambridge: Polity Press, 2015.

DIAS, T. S. "'É uma batalha de narrativas': os enquadramentos de ação coletiva em torno do impeachment de Dilma Rousseff no Facebook". Ciência Política. Dissertação de mestrado. Universidade de Brasília, Brasília, 2017.

ESTANQUE, E. "Rebeliões de classe média? Precariedade e movimentos sociais em Portugal e no Brasil (2011-2013)". Revista Crítica de Ciências Sociais, no 103, p. 53-80, 2014.

FRANZOSI, R. "The press as a source of socio-historical data: Issues in the methodology of data collection from newspapers". Historical Methodes, vol. 20, p. 5-16, 1987.

FundaçÃo Perseu Abramo. Projeto "Manifestações de março", survey comparativo de 13 e 18, 2015/2016, 2016. Disponível em: <http://novo.fpabramo.org.br/sites/default/files/FPA-PesquisaManifestacoes-Comparativa-2015-2016-SITE-042016-ok.pdf>. Acesso em: 20 abr. 2016.

GALVÃo, A. A reconfiguração do movimento sindical nos governos Lula. In: BoITo, A.; GALVÃo, A. (orgs.). Política e classes sociais no Brasil dos anos 2000. São Paulo: Alameda, p. 187-221, 2012.

GALVÃO, A. Labour conflicts and union strategies in Dilma Rousseff's governments. In: FERRERO, J. P.; NATALUCCI, A.; TATAGIBA, L. (eds.). Socio-political dynamics within the crisis of the left turn: Argentina e Brazil. Londres: Rowman \& Littlefield, 2019.

GalvÃo, A.; MARCELINo, P. "Balanço da atuação do sindicalismo brasileiro no século XXI: os governos do PT, o golpe e as contrarreformas". Latin American Perspectives, 2019 (no prelo). 
Galvão, A.; TATAgiBA, L. "Por uma análise integrada do confronto político". Relatório de pesquisa do projeto "O confronto político da ascensão à crise dos governos petistas (2003-2016)". Campinas: Universidade Estadual de Campinas, Nepac/Cemarx, 2018.

GoHn, M. G. Manifestações de junho de 2013 no Brasil e praças dos indignados no mundo. Petrópolis: Vozes, 2014.

GomeS, C.; SORJ, B. "Corpo, geração e identidade: a Marcha das Vadias no Brasil". Sociedade e Estado, vol. 29, no 2, p. 433-447, 2014.

Grasso, M. T.; GIUGNI, M. "Protest participation and economic crisis: the conditioning role of political opportunities". European Journal of Political Research, vol. 55, n 4, p. 663-680, 2016.

HeTLAND, G.; Goodwin, J. The strange disappearance of capitalism from social movement studies. In: Colin, B., et al. (eds.). Marxism and social movements. Leiden/Boston: Brill, p. 83-102, 2013.

HUTTER, S. Protest event analysis. In: PORTA, D. (org.). Methodological practices in social movement research. Oxford: Oxford University Press, p. 335-367, 2014.

Johnson, P. B.; SeARs, D. O.; Mcconahay, J. B. "Black invisibility, the press, and the Los Angeles riot". American Journal of Sociology, vol. 76, p. 698-721, 1971.

Klandermans, B.; StAggenborg, S. (eds.). Methods of social movements research. Minneapolis: University of Minnesota Press, 2002.

Koopmans, R.; RuCht, D. Protest event analyzes. In: KLAndermans, B.; STAggenborg, S. (eds.). Methods of social movements research. Minneapolis: University of Minnesota Press, 2002.

Koopmans, R.; NeIdhardt, F.; Rucht, D. (eds.). Acts of dissent: new development in the study of protest. Lanham: Rowman \& Littlefield, 1999.

MedeIROS, J.; FANTI, F. Recent changes in the Brazilian feminist movement field: the emergence of new collective actors. In: FerRero, J.; NATAlucci, A.; TATAgiBA, L. (eds.). Socio-political dynamics within the crisis of the left turn: Argentina and Brazil. Londres: Rowman and Littlefield, 2019.

Miguel, L. F. "Polarização política: um discurso enganoso". Carta Maior, 30/4/2018. Disponível em: <https://www.cartamaior.com.br/?/Editoria/Politica/Polarizacao-politica-um-discursoenganoso/4/40051>. Acesso em: 5 maio 2018.

OLSAK, S. "Analysis of events in the study of collective action". Annual Review of Sociology, vol. 15, p. $119-141,1989$.

Ortellado, P.; Solano, E.; Ribeiro, M. Uma sociedade polarizada?. In: Jinkings, I.; Doria, K.; Cleto, M. (orgs.). Por que gritamos golpe?. São Paulo: Boitempo, p. 159-164, 2016.

PURDY, S. "Brazil's June days of 2013: mass protest, class, and the left". Latin American Perspectives, vol. 44, 2017.

RidENTI, M. "Brasil, junio de 2013: la historia de nuevo en las calles". Fundación Mapfre Historia, Debate y Perspectivas (blog), dez. 2013a.

. "La hora y la vez de los jóvenes en Brasil". Fundación Mapfre Historia, Debate y Perspectivas (blog), dez. 2013b.

Rossi, P.; DWECK, E.; OlIVEIRA, A. L. Economia para poucos: impactos sociais da austeridade e alternativas para o Brasil. São Paulo: Autonomia Literária, 2018.

SAAD-FILHO, A.; BoITO, A. "Brazil: the failure of the PT and the rise of the 'new right'". Socialist Register, London, vol. 52, p. 213-230, 2016. 
SADER, E. Quando novos personagens entraram em cena: experiências, falas e lutas dos trabalhadores da grande São Paulo (1970-80). 2a ed. São Paulo: Paz e Terra, 1995.

SILVA, M. K. Movimentos, contramovimentos e destituição presidencial no Brasil. Mimeo, 2017.

Silva, M. K.; Araujo, G. O; Pereira, M. M. Análise de eventos de protesto no estudo dos repertórios associativos. In: ROBERTT, P., et al. (orgs.). Metodologia em ciências sociais hoje: práticas, abordagens e experiências de investigação. Jundiaí: Paco Editorial, p. 311-330, 2016.

Singer, A. Os sentidos do lulismo. Reforma gradual e pacto conservador. São Paulo: Companhia das Letras, 2012. 23-40, 2013.

. "Brasil, junho de 2013, classes e ideologias cruzadas". Novos Estudos Cebrap, n 97, p.

"Cutucando onças com varas curtas: o ensaio desenvolvimentista no primeiro mandato de Dilma Rousseff (2011-2014)". Novos Estudos Cebrap, no 102, p. 42-71, 2015.

Singer, A.; Loureiro, I. (orgs.). As contradições do lulismo. A que ponto chegamos?. São Paulo: Boitempo, 2016.

TATAGiBA, L. "Os protestos e a crise brasileira. Inventário inicial das direitas em movimento". Sinais Sociais, Rio de Janeiro, vol. 11, n³3, p. 11-38, 2017.

"Entre as ruas e as instituições. Os protestos e o impeachment de Dilma Rousseff". Lusotopie, vol. 17, $\mathrm{n}^{\circ} 1$, p. 112-135, 2018.

. Crossroad of Brazilian democracy. Dynamics of social mobilisation during left turn cycle. In: FerReRo, J.; TATAGiba, L.; NATAluCCI, A. (eds.). Socio-political dynamics within the crisis of the left turn: Argentina and Brazil. Londres: Rowman and Littlefield, 2019.

TATAgiba, L.; Galvẽo, A. "O confronto político da ascensão à crise dos governos petistas". Banco de dados sobre protestos no Brasil 2003-2016. Universidade Estadual de Campinas, Nepac/Cemarx, Campinas, 2018.

Tatagiba, L.; Trindade, T.; Teixeira, A. C. Protestos à direita no Brasil (1997-2015). In: Cruz, S. V.; KAYSEL, A.; CODAS, G. (orgs.). Direita, volver! O retorno da direita e o ciclo político brasileiro. São Paulo: Fundação Perseu Abramo, p. 197-212, 2015.

TilLy, C. From mobilization to revolution. Reading: Addison Wesley, 1978.

ZANINE, D.; TATAGIBA, L. Between the streets and Facebook: engaged action in the pro-impeachment campaign in Brazil (2014-2016). In: FerRero, J.; TATAGiBA, L.; NATAlucCI, A. (eds.). Socio-political dynamics within the crisis of the left turn: Argentina and Brazil. Londres: Rowman and Littlefield, 2019.

\section{Abstract}

Protests in Brazil in times of crisis (2011-2016)

This article proposes analyzing the characteristics of the protests in Brazil between 2011 and 2016, a socio-economic and political context marked by the contradictions and the decline of the PT's government. The analysis is based on a protest database drawing from the Folha de São Paulo newspaper. We hold that the protests precede the outbreak of the economic crisis and when the peak in 2013 is reached, they produce changes in the political context, opening unprecedented political opportunities for a heterogeneous set of actors, on both to the right and to the left of the PT, to manifest their differences in relation to the government. The protests show the limits of the PT's class conciliation politics and constitute the scenario of instability that contributed to Rousseff's 
impeachment, so there is no discontinuity between 2013 and 2015-2016. The pattern of protest in this period is characterized by the combination of two distinct dynamics: political polarization and heterogenization of actors and claims.

Keywords: protests; crisis; PT governments

\section{Resumen}

Las protestas en Brasil en época de crisis (2011-2016)

Este artículo se propone analizar las características de las protestas en Brasil entre 2011 y 2016 , un contexto socioeconómico y político marcado por las contradicciones y por el ocaso de los gobiernos petistas. El análisis está basado en un banco de datos de protesta constituido a partir del diario Folha de São Paulo. Sostenemos que las protestas preceden a la eclosión de la crisis económica y que cuando alcanzan el pico en 2013, producen cambios en el contexto político, abriendo oportunidades políticas inéditas para que un conjunto heterogéneo de actores, a la derecha y a la izquierda del PT, manifestara sus divergencias con relación al gobierno. Las protestas evidencian los límites de la política de conciliación de clases de los gobiernos petistas y conforman un escenario de inestabilidad que contribuye a la destitución de Rousseff, de modo que no hay una discontinuidad entre 2013 y 2015 2016. El patrón de protesta verificado en ese período se caracteriza por la combinación de dos dinámicas distintas: polarización política y heterogeneización de actores y reivindicaciones.

Palabras clave: protestas; crisis; gobiernos petistas

\section{Résumé}

Les protestations au Brésil en période de crise (2011-2016)

Le but de cet article est d'analyser les caractéristiques des protestations au Brésil entre 2011 et 2016 , un contexte socio-économique et politique marqué par les contradictions et le déclin des gouvernements du PT. L'analyse est fondée sur une base de données de protestations constituée à partir du journal Folha de São Paulo. Nous soutenons que les protestations précèdent le déclenchement de la crise économique et que, lorsqu'elles atteignent leur apogée en 2013, elles modifient le contexte politique, ouvrant des opportunités politiques inédites pour qu'un ensemble hétérogène d'acteurs, à droite et à gauche du PT, manifestent leurs différences par rapport au gouvernement. Les protestations mettent en évidence les limites de la politique de conciliation de classe du PT et constituent un scénario d'instabilité qui contribue à la destitution de Rousseff, de sorte qu'il n'y ait pas de discontinuité entre 2013 et 2015-2016. Le schéma de protestation observé pendant cette période est caractérisé par la combinaison de deux dynamiques distinctes: la polarisation politique et I'hétérogénéisation des acteurs et des revendications.

Mot clés: protestations; crise; gouvernements du PT

Artigo submetido à publicação em 12 de setembro de 2018. Versão final aprovada em 13 de março de 2019.

Opinião Pública adota a licença Creative Commons CC-BY. 
Opinião Pública, DOI 10.1590/1807-019120192521 errata

\section{Errata}

Errata ao artigo "Os protestos no Brasil em tempos de crise (20112016)", de Luciana Tatagiba e Andréia Galvão, publicado no periódico Opinião Pública, vol. 25, n. 1, p. 63-96, com número de DOI 10.1590/1807-0191201925163, na página 74, em fonte do Gráfico 4:

Onde se lia:

Fonte: Elaborado pelas autoras, a partir de dados do IBGE, Diretoria de Pesquisas, Coordenação de Contas Nacionais e Tatagiba e Galvão (2018).

Leia-se:

Fonte: Elaborado pelas autoras a partir do Sistema de Acompanhamento de Greves-Dieese. Dados compilados em 2017, parciais para os anos de 2014 e 2015.

Opinião Pública adota a licença Creative Commons CC-BY. 